\title{
Dietary phyto-oestrogens: molecular mechanisms, bioavailability and importance to menopausal health
}

\author{
Aedín Cassidy \\ School of Medicine, Health Policy and Practice, University of East Anglia, Norwich NR4 7TJ, UK
}

\begin{abstract}
Following the high-profile studies on hormone replacement therapy which provided little evidence in support of the drug therapy improving future health, there remains a growing demand for dietary solutions for maintaining health and preventing disease as women age. Although interest in the relative importance of phyto-oestrogens to human health has increased dramatically over the last decade, the effective dose for health benefits and hypothetical issues on safety remain to be resolved. Plausible mechanisms and epidemiological data are available to support the concept that phyto-oestrogen-rich diets exert physiological effects, but optimal doses and sources of these compounds have still not been elucidated for specific health benefits. In addition, much of the current mechanistic data are difficult to interpret as the experiments have incorporated levels of phyto-oestrogens that may not be achievable in vivo and have to date only used aglycones and glycosides of the pure compounds rather than examining the biological effects of gut and liver metabolites. The present review will concentrate on the isoflavone subclass of phyto-oestrogens, as, to date, these compounds have received most attention from both a commercial and research perspective.
\end{abstract}

Phyto-oestrogens: Menopausal women: Disease prevention: Isoflavones

\section{Introduction}

Phyto-oestrogens are multi-faceted compounds; however, to date, much of the interest in their biological activity has related to oestrogen receptor (ER)-mediated mechanisms, but the relative importance of non-oestrogenic mechanisms of action in defining their relative importance to human health has been gaining momentum, particularly in relation to women's health. The well-publicised results of two largescale hormone replacement therapy (HRT) trials, the Women's Health Initiative in the USA and the Million Women's study in the UK, showing evidence of an increased risk of combined HRT on breast cancer, heart disease, stroke and venous thromboembolism (Rossouw et al. 2002; Banks et al. 2003) have led to the conclusion that HRT will not protect future health although short-term use remains beneficial for severe menopausal symptom relief (McPherson, 2004). Since the justification for long-term HRT can no longer be applied for disease prevention, women continue to seek alternative 'natural' options, such as phyto-oestrogens, to improve their quality of life and reduce their risk of disease. However, many are unaware of the limited scientific evidence of safety and efficacy of such natural therapies.

Traditionally, phyto-oestrogens have been considered to be weakly oestrogenic and it is well established that serum levels of isoflavones following consumption of a modest intake of soya foods can reach the low micromolar level, about 100-1000 times that of oestradiol. Therefore, even if these compounds have a weak potency, they have the potential to exert biological effects in vivo; such effects have been reported in several trials using a range of different endpoints (Cassidy et al. 1994, 1995; Nestel et al. 1999; Davis et al. 2001; Djuric et al. 2001). The biological action of phyto-oestrogens is complex and their ultimate cellular actions are determined by many factors including the relative levels of $E R \alpha$ and $\beta$, the diverse mixture of coactivators and co-repressors present in any given cell type, and the nature of the response elements with which the receptors interact and modulate gene expression (Montano $\&$ Katzenellenbogen, 1997). It is thus not surprising that the resulting effects observed from available in vitro and in vivo experiments are inconsistent, since the biological effects vary depending on the phyto-oestrogen compound studied, cell line used, and the species and tissue under examination. Numerous other biological effects independent of the ER (for example; antioxidant capacity, antiproliferative and anti-angiogenic effects) have been ascribed to phytooestrogens, and many of these mechanisms are common to other plant phenolics (Setchell \& Cassidy, 1999).

Abbreviations: ER, oestrogen receptor; HRT, hormone replacement therapy.

Corresponding author: Professor Aedín Cassidy, fax +44 1603 593752, email a.cassidy@uea.ac.uk 


\section{Molecular mechanisms of action}

\section{Oestrogen receptor-mediated mechanisms of action}

Until recently the predominant research on the mechanisms of action of phyto-oestrogens has concentrated on their ER-mediated effects. The oestrogenic activity of isoflavones was first described in the 1940s when infertility of sheep in Western Australia was caused by ingestion of clover rich in the isoflavone precursors, formononetin and biochanin A (Bennetts et al. 1946). These animal data, together with their similar spatial conformation to mammalian oestrogens (Fig. 1) and ability to bind to ER and alter oestrogenregulated genes (Markiewicz et al. 1993), stimulated interest in the oestrogenic proprieties of isoflavones.

Traditionally, isoflavones have been considered to be weakly oestrogenic compared with $17-\beta$ oestradiol, but with divergent estimates of oestrogenicity depending on the assay system used. In vitro, concentrations of phytooestrogens equivalent to humans consuming a moderate phyto-oestrogen intake stimulate cell growth in oestrogenpositive, but not oestrogen-negative cells. In contrast, very high concentrations (possibly achievable from supplement intake) inhibit cell growth in both ER-positive and -negative cell lines (Zava et al. 1997; Sathyamoorthy et al. 1998; Miodini et al. 1999). Nevertheless, the estimates of oestrogenicity suggest that these compounds have the capacity to exert physiological effects in vivo because serum levels of phyto-oestrogens following the consumption of soya will exceed endogenous oestrogen levels by several orders of magnitude (Axelson et al. 1984; Adlercreutz \& Mazur, 1997). In addition, isoflavones may be more available to tissues by binding less tightly to serum proteins than oestrogens (Nagel et al. 1998) and tissueselective effects are possible given the higher binding affinity of isoflavones to ER $\beta$ compared with ER $\alpha$ (Kuiper et al. 1997, 1998) and the different tissue distribution of this receptor sub-type (Couse et al. 1997; Nilsson et al. 1998; Cassidy \& Faughnan, 2000). Oestrogens and isoflavones also have wide differences in transcriptional activity which results not only from their differences in binding affinities but also from differences in their ability to recruit coregulators and trigger transcriptional functions of $\mathrm{ER} \alpha$ and ER $\beta$ (An et al. 2001). The isoflavone gensitein has 1000fold greater potency at triggering transcriptional activity with ER $\beta$ than ER $\alpha$ (Pike et al. 1999; An et al. 2001). Therefore, understanding the role of ER $\beta$ in different tissues is critical in further understanding the role of isoflavones in specific diseases.

\section{Non-oestrogen receptor-mediated mechanisms of action}

Many mechanisms of action of isoflavones occur without direct interaction with ER including influencing cell signalling, cell division and growth and gene expression. Specifically, the isoflavone genistein in vitro inhibits enzymes involved in oestrogen and androgen metabolism, and inhibits tyrosine kinase activity, angiogenesis and DNA repair enzymes (Akiyama et al. 1987; Kao et al. 1998; Kim et al. 1998). However, in vitro many of these inhibitory effects occur only at levels that exceed $25 \mu \mathrm{mol}$ (Barnes et al. 2000). This contrasts to peak genistein levels of about $5 \mu \mathrm{mol}$ following in vivo soya consumption, and most of this genistein will be conjugated with glucuronic acid and therefore less biologically active. It is therefore unclear how relevant such in vitro findings are to man.

Isoflavones possess antioxidant properties; however, to date most studies have focused predominantly on the antioxidant effects of the isoflavone precursor, genistein (Wei et al. 1993; Rimbach et al. 2004). It has been demonstrated that genistein is a more effective antioxidant than daidzein, and this is probably attributable to the presence of a third hydroxyl group in the C-5 position. Interestingly, the gut metabolite of daidzein, equol, is a more potent antioxidant than either daidzein or genistein or the parent glycosides, suggesting that the absence of the 2,3-double bond in conjunction with a loss of the<smiles>COc1c(O)cc2occ(-c3ccc(O)cc3)c(=O)c2c1O</smiles>

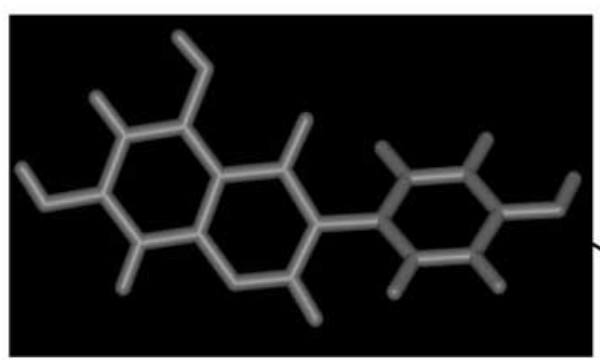

Genistein

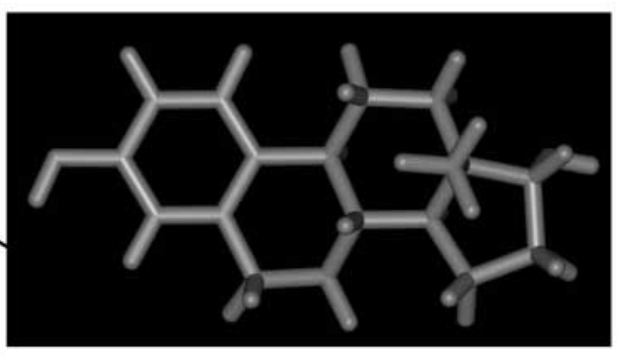

Oestradiol

Fig. 1. The chemical structures of the isoflavone aglycones, daidzein, genistein and glycitein and a three-dimensional comparison of the structure of genistein and the female hormone oestradiol. 
4-oxo group enhances antioxidant properties (Arora et al. 1998). Antioxidant activity, assessed by the trolox equivalent antioxidant capacity (TEAC) assay also suggests that equol is a more potent isoflavone compared with genistein and daidzein (Mitchell et al. 1998). Proposed molecular mechanisms responsible for their antioxidant potential include the ability to scavenge radicals, chelate metals, inhibit $\mathrm{H}_{2} \mathrm{O}_{2}$ production and stimulate antioxidant enzymes, including catalase (Fig. 2). The ability of isoflavones to scavenge hydroxyl, superoxide, NO, diphenylpicrylhydrazyl, galvinoxyl, and lipid-derived radicals has also been investigated with no significant scavenging effects on these radicals at concentrations up to $1.0 \mathrm{~mm}$ for a range of isoflavones (Guo et al. 2002a,b). However, at a concentration of $5 \mathrm{nM}$, both genistein and daidzein resulted in modest increases in intracellular-reduced glutathione levels in human endothelial cells, while cellular $\alpha$ tocopherol and uric acid remained unchanged following isoflavone treatment. These data suggest that the free radical-scavenging activities of the isoflavones tested may not substantially contribute to their antioxidant properties, and the ability of genistein and daidzein to increase cellular reduced glutathione may make a more significant contribution to their biological action. Recent data suggest that sulfation of genistein, with the associated loss of hydroxyl groups, decreases its beneficial activity on platelet aggregation and inflammation, as well as cell adhesion and chemotaxis (Rimbach et al. 2004; Turner et al. 2004).

\section{Food sources}

The most extensively studied class of the phyto-oestrogens, the isoflavones, occurs largely in soyabeans and a few other legumes (Coward et al. 1993). To date, twelve different soyabean isoflavone isomers have been identified. Most dietary sources contain a mixture of derivatives based on the isoflavone aglycones, daidzein, genistein and glycitein
(Fig. 1). As well as the aglycone form, isoflavones may be present in soya foods as glucosides, acetyl glucosides or malonyl glucosides. Typically, soyabeans and soya foods contain more genistein than daidzein (Murphy et al. 1999).

Although all soyabean-derived protein extracts and foods available for human consumption contain significant levels of isoflavones, there is large variability in concentration and profile among these products that depends on species, geographical and environmental conditions, and the extent of industrial processing of the soyabeans (Coward et al. 1993). However, even for a given brand of soya product, recent data suggest significant variation in isoflavone levels over time (Setchell \& Cole, 2003). These data reinforce the importance of accurately defining the isoflavone content of foods or supplements used in clinical intervention trials and question the validity of setting up databases with phytooestrogen content of foods designed to estimate isoflavone content of the diet.

There are numerous commercial phyto-oestrogen supplements available, which are predominantly promoted for their value in treating postmenopausal conditions. These are made from a variety of sources, including concentrated soyabean extracts, or an extract of red clover. However, to date there are limited data examining the relative clinical effectiveness of specific preparations, and analytical data suggest that quality assurance is a significant issue with commonly available isoflavone supplements (Setchell et al. 2001). In particular, since dietary supplements and some foods enriched in phyto-oestrogens contain comparatively high amounts of these compounds, consumers may be exposed to high concentrations and the relative risk:benefit from such consumption over the short and longer term warrants further investigation in clinical trials.

In general, Western populations consume low levels of isoflavones because few foods included in the typical Western diet contain soya protein, the fraction with which isoflavones are associated. The average daily dietary intake

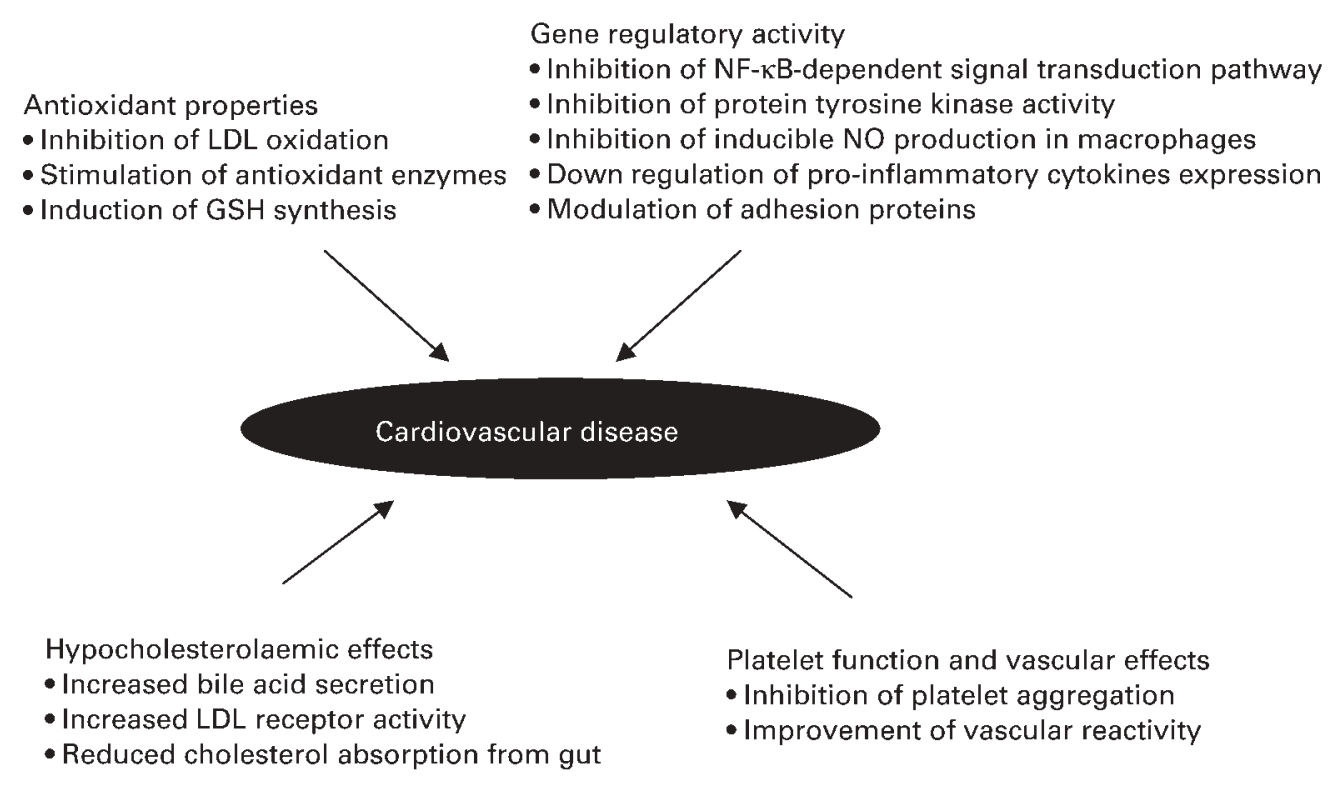

Fig. 2. Proposed molecular mechanisms of action of isoflavones on CVD risk. 
of isoflavones among Western populations is negligible $(<1 \mathrm{mg} / \mathrm{d}$; Setchell \& Cassidy, 1999) and the lack of these dietary phytoprotectants is viewed as one explanation for the disparity in disease incidence rates between Western and Asian populations.

Soya has been a traditional staple in Far Eastern countries for generations, and the lower incidences of osteoporosis, breast cancer, and menopausal symptoms among women who consume soya as a dietary staple have been suggested in part to be due to the high intake of isoflavones (Axelson et al. 1984; Setchell et al. 1984; Adlercreutz et al. 1986). In the early 1990s estimates of intakes in Asian countries were in the region of $100 \mathrm{mg}$ isoflavones/d but these data are now acknowledged as overestimates. As the methods of analysis of levels in foods have been improved there has been a move towards a consistent form of reporting of intake in aglycone equivalents (converted from glucosides using the appropriate ratios of molecular weights). More recent estimates of the amounts of soya food consumed in Japan indicate typical isoflavone intakes of $11-40 \mathrm{mg} / \mathrm{d}$ (reported as aglycone equivalents to standardise doses between different foods) in adults (Nagata et al. 1998; Munro et al. 2003). This would convert to $18-63 \mathrm{mg} / \mathrm{d}$ as the glucoside using 1.61 as the conversion factor based on the ratios of genistein, daidzein and glycitein in the most commonly consumed foods (Beecher et al. 1999). However, it is difficult to determine the precise isoflavone intake in countries such as China, Korea, Indonesia and Japan. Food and eating trends are changing rapidly, intake levels may vary between urban and rural areas, and intake is affected by generational and lifestyle differences. However, data from several studies suggest that intakes of $60 \mathrm{mg}$ isoflavones (expressed aglycone equivalents)/d is not uncommon, with intake levels ranging from 32 to $66 \mathrm{mg}$ aglycone equivalents in several recent studies (Seow et al. 1998; Chen et al. 1999; Wakai et al. 1999). The most widely used soya products, soya oil, soya sauce, and soya lecithin, do not have significant levels of isoflavones, and this is also the case for aqueous alcohol-washed soya proteins (Coward et al. 1993).

\section{The equol phenotype}

Equol does not naturally occur in plants but is a specific bacterial metabolite, which is found in high concentrations in urine and plasma following the consumption of isoflavone-rich foods (Axelson et al. 1982, 1984). Our recent data, using stable isotopes of the pure compounds, showed conclusively that it is a metabolite specifically formed following daidzein consumption (Setchell et al. $2003 b$ ).

The consistent observation that all adults do not synthesise equol in response to challenges from soya foods or isoflavones has led to the realisation that there are two distinct sub-groups of the population, defined as 'equol producers' and 'non-equol producers'. The factors governing equol production remain poorly understood (Lampe et al. 1998; Rowland et al. 1999, 2003; Setchell et al. $2002 b$ ), but emerging data from clinical studies suggest that the ability to produce equol following the ingestion of soya isoflavones may be a significant factor in the clinical effectiveness to soya diets. This factor has not previously been considered in the design of dietary intervention studies examining the effectiveness of soya diets (Setchell et al. $2002 b$ ). The greater efficacy of soya diets in subjects who can make equol and the paucity of data on the bacteriology involved in its production present challenges for developing strategies to convert non-equol producers into equol producers, as this metabolite may be important in explaining the potential efficacy of isoflavones.

Equol production may enhance the action of isoflavones as it has a lower affinity for serum proteins, greater affinity for ER compared with its precursors, daidzein and dihydrodaidzein and exerts superior antioxidant activity (Shutt \& Cox, 1972; Hodgson et al. 1996; Arora et al. 1998). Equol exists in two enantiomeric forms, $\mathrm{S}$ and $\mathrm{R}$ equol, and recent data suggest that only the $S$ isomer is present in man (Setchell et al. 2002a).

The hormonal activity of equol was first evident in human subjects when high inter-individual variation in the excretion of equol was observed in volunteers who were taking $45 \mathrm{mg}$ isoflavones/d (Cassidy et al. 1994, 1995). Following this consumption of isoflavones from soya, a significant increase in menstrual cycle length was observed, a finding that was not observed when soya devoid of isoflavones were fed. Follicular phase length was correlated with urinary equol excretion, adding weight to the evidence that equol is a more potent isoflavone. A significant amount of literature exists on the biological and clinical effectiveness of soya in relation to heart disease, bone health, menopausal symptoms and hormone-dependent cancers, with wide variability in responses reported. This variability in response may be related to subjects' ability to produce equol as it is well established that only $30-40 \%$ of any given population group studied can produce equol (Cassidy et al. 1994, 1995; Rowland et al. 2003; Atkinson et al. 2005). However, in two recent studies there have been inconsistent results. No significant differences in serum hormone concentrations were observed in postmenopausal women in relation to equol phenotype (Frankenfeld et al. 2004), while in a group of premenopausal women the equol producers had lower serum concentrations of oestrogen and androgens (Duncan et al. 2000).

An inability to produce equol may be related to an absence of appropriate enzymes in the intestinal microflora or absence of bacterial species capable of producing equol (Adlercreutz et al. 1981; Setchell et al. 1984). Its formation is exclusively related to intestinal microflora as germ-free rats do not excrete equol (Adlercreutz et al. 1981; Axelson et al. 1982) and the absence of equol from infant blood samples following soya infant formula ingestion add weight to the need for an active microflora for its formation (Setchell et al. 1997).

The metabolism of isoflavones in animals and man is complex and is a combination of both mammalian and gut microbial processes (Setchell \& Cassidy, 1999; Rowland et al. 2003). Factors that may be important in influencing the large interindividual variation in the metabolism and excretion of isoflavones, particularly with respect to equol, are complex but relate to the composition of diet and the human gut microflora (Lampe et al. 1998; Setchell \& Cassidy, 1999; Rowland et al. 2000). Prospective intervention studies in equol-producing subjects are required 
to further elucidate factors governing the conversion of daidzein to equol and to determine the potential role of prebiotics in influencing the ability of individuals to convert daidzein to equol in the large gut. In addition, determining its potential clinical significance merits further investigation in human intervention studies.

\section{Bioavailability}

Bioavailability of phyto-oestrogens is based on data from absorption, metabolism, distribution and excretion studies conducted both in human subjects and animals. Following the consumption of either pure compounds, isoflavone-rich extracts, or foods or beverages rich in isoflavones, the parent compounds and their metabolites can be detected in the plasma and urine of human volunteers. Most of the available pharmacokinetic data on phyto-oestrogens relate to levels attained in plasma and urine of specific isoflavones and their metabolites; for example, daidzein and genistein.

After ingestion, isoflavones are hydrolysed by intestinal glucosidases, which release the aglycones daidzein, gensitein and glycitein (Fig. 3). These may be absorbed or further metabolised to many specific metabolites including equol and p-ethyl phenol (Axelson et al. 1984; Bannwart et al. 1984; Kelly et al. 1993; Joannou et al. 1995). Because there are currently no guidelines on optimal levels of isoflavones and there are limited data on their bioavilability from foods (Xu et al. 1994; Setchell et al. 2001, 2003a,b), dietary intakes in clinical studies examining the risks and benefits of isoflavones for human health have to date been empirically derived. The daily intake of about $50 \mathrm{mg}$ isoflavone glucosides/d which has predominantly been used in clinical intervention studies appears to be largely based on our earlier observation that daily consumption of soya foods containing $45 \mathrm{mg}$ isoflavone glucosides caused endocrine modulation of the menstrual cycle in healthy premenopausal women (Cassidy et al. 1994, 1995). More recently there has been a tendency to use relatively large dietary intakes of soya isoflavones derived from foods or supplements far exceeding typical consumption levels in Asian countries (Nagata et al. 1998; Chen et al. 1999; Wakai et al. 1999). However, the rationale for these higher intakes remains unclear and is not based on knowledge of their pharmacokinetic behaviour. As with pharmacological compounds, demonstrating efficacy of soya and its isoflavones requires knowledge of their bioavailability, but, to date, there is limited information on how this varies among subjects and whether it is influenced by age or other factors.

Although it is well established that infants, in contrast to adults, are unable to metabolise isoflavones (Setchell et al. 1997), to date there are limited data available examining the effect of age on isoflavone metabolism and absorption in later life. This is particularly important since much of the current interest in relation to isoflavones relates to the health of postmenopausal women. However, to date, many studies investigating the biological effects of these compounds have been carried out in premenopausal women (Cassidy et al. 1994, 1995). Furthermore, the influence of sex is contentious, with several studies suggesting that urinary isoflavone kinetics are not related to sex (Setchell et al. 1984; Kelly et al. 1993; Kirkman et al. 1995; Lampe et al. 1998), while others are suggestive of a sex difference in absorption and metabolism of these compounds ( $\mathrm{Lu} \&$ Anderson, 1998).

In Asian countries where soya is consumed as a staple it remains to be determined if the chemical composition of the soya food alters absorption and metabolism and thus potential biological efficacy of soya isoflavones. Asian populations have traditionally consumed primarily fermented soya protein products, and since these foods contain a higher proportion of aglycone isoflavones, it has been suggested that they may be more bioavailable since these aglycone isoflavones do not require hydrolysis in the intestine before absorption. There are preliminary suggestions that urinary recoveries of daidzein and genistein following the ingestion of fermented soya foods may be greater (Cassidy et al. 1995; Hutchins et al. 1995), but this contrasts with recent data on the pure compounds which suggests no differences in the apparent bioavailability of pure daidzein and gensitein tablets when consumed as either aglycones or glycosides (Zubik \& Meydani, 2003). Although in their purified form, daidzein and genistein aglycones are more rapidly absorbed into the systemic circulation (Izumi et al. 2000; Setchell et al. 2001), other data suggest that the overall systemic bioavailability of the pure aglycone compounds was lower compared with their glycoside forms (daidzin and genistin) (Setchell et al. 2001). However, whether the same effects are observed when subjects are fed different soya foods containing isoflavones in the conjugated or unconjugated form remains to be investigated.

In human intervention trials investigating the biological effects of these compounds in relation to human health,

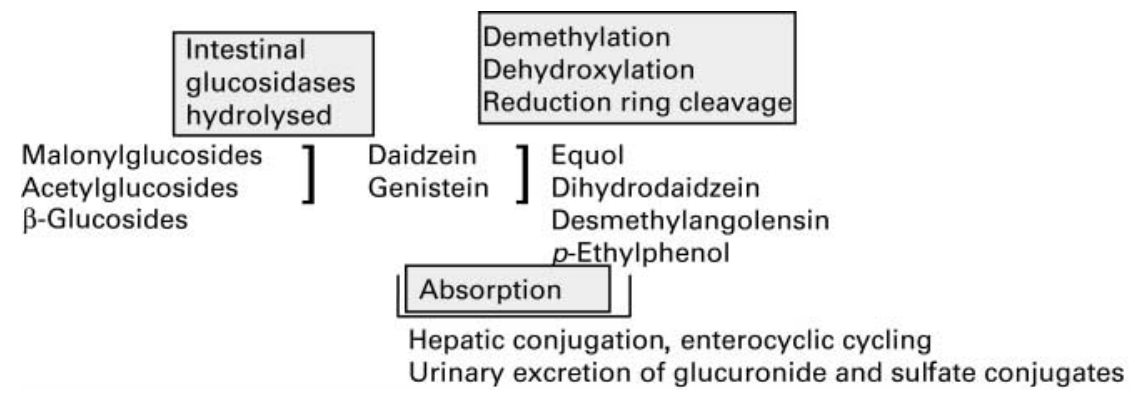

Fig. 3. Absorption and metabolism of isoflavones in man. 
urinary phyto-oestrogens are frequently used as a biomarker of their potential bioavailability from foods or supplements rich in these compounds, in part because urine is an easier biological sample to collect, and because urine contains 100-fold higher concentrations of isoflavones (Cassidy et al. 1994; Setchell et al. 2001, 2003b). Our recent data from pharmacokinetic studies using stable isotopes of the pure isoflavone compounds, daidzein and gensitein, suggest that the collection of random 'spot' urine samples does not correlate with serum measurements, but $24 \mathrm{~h}$ urine collections monitored for completeness with an exogenous marker correlate well with serum assessment of systemic bioavailability of these compounds (Setchell et al. 2003b). Additionally, quantitative assessment in urine provides information on the extent of intestinal metabolism of isoflavones and provides information on subject compliance within soya intervention trials.

Knowledge of the pharmacokinetics of phyto-oestrogens is essential before making recommendations regarding long-term efficacy in clinical studies, as recent research suggests significant differences in bioavailability between foods rich in phyto-oestrogens, and supplements (Setchell et al. 2003c; Faughnan et al. 2004). In addition, the dose administered, food matrix and the chemical form of the compound appear to exert effects on the bioavailability (Faughnan et al. 2004). Maintenance of a steady-state serum level should be optimal for clinical effectiveness of these compounds and on the basis of current pharmacokinetic data, this would be best achieved by divided doses of the soya food or supplement throughout the day, rather than by a single dose. The available absorption and metabolism data for these compounds suggest that levels attained in plasma do not increase in a linear fashion with increased intake (Setchell et al. 2003c; Faughnan et al. 2004), suggesting limited advantage in consuming high levels of these compounds through functional foods and supplements, but data on the levels attained in plasma following mega-dosing of these compounds warrant further investigation. Importantly, increases in the concentrations of isoflavones and its associated metabolites in plasma and urine do not necessarily mean that they have additional effects in vivo.

\section{Potential health effects}

The international variation in CVD, osteoporosis, menopausal symptoms, breast and prostate cancer has stimulated interest in the role of isoflavones in the diet as potentially protective components. In Asia, where urine and plasma levels of isoflavones are high, these conditions are rare (Adlercreutz et al. 1986). However, to date, clinical studies that have examined the potential of isoflavones to cause physiological effects in human subjects have been limited to epidemiological studies, or to dietary intervention trials that have examined effects on menopausal symptoms, cardiovascular function, and endocrine regulation of the menstrual cycle. Overall, these dietary studies have shown effects that may be interpreted as beneficial, but it is difficult to tease out the precise contribution that isoflavones play in the overall endpoints measured. In particular, we have insufficient data to ascertain the optimal dose of isoflavone necessary to exert specific clinical effects (Setchell \& Cassidy, 1999).

\section{Breast cancer}

Interest in the potential role of phyto-oestrogens in reducing risk of breast cancer stemmed from the intriguing epidemiological data showing low breast cancer incidence in Asian countries where soya is more frequently consumed. Associations between consumption of isoflavone-containing foods (soya) and breast cancer risk have been inconsistent and were recently reviewed (Peeters et al. 2003); however, in a recent prospective cohort study in Japan, consumption of isoflavones from foods was inversely related to risk of breast cancer, with the greatest reduction of risk for postmenopausal women (Yamamoto et al. 2003).

Although sex steroid hormones play a central role in breast carcinogenesis, evidence from in vitro and animal studies suggest that phyto-oestrogens may inhibit the development of mammary tumours through their role in regulating the synthesis, metabolism and signal transduction of steroid hormones (Barnes, 1998; Messina \& Loprinzi, 2001). The molecular mechanisms involved in potentially explaining the cancer-preventative properties of isoflavones are not completely understood and may only be partially mediated by the alteration of ER-dependent pathways, as isoflavones can exert hormonal and anti-oestrogenic effects either with or without direct interaction with ER; in vitro isoflavones inhibit enzymes involved in oestrogen metabolism, inhibit aromatase and inhibit $17 \beta$ oxidoreduction of oestrogens (at relatively low micromolar concentrations) (Ibrahim \& Abulhajj, 1990; Kao et al. 1998; Le Lain et al. 2001). Low concentrations of isoflavones also inhibit hydroxysteroid dehydrogenase (Makela et al. 1998; Wahala \& Alho, 2002). This is together with the other described mechanisms of action including inhibition of tyrosine kinase, DNA topoisomerases, angiogenesis and antioxidant effects (Setchell \& Cassidy, 1999). It is thought that oestrogens, which drive the growth of oestrogen-sensitive mammary tumours, are generated locally; thus the effects of isoflavones on oestrogen metabolism at the tissue level may be important but have yet to be investigated.

The established relationship between breast cancer and steroid hormone status (Clemons \& Goss, 2001), the structural similarity of isoflavones to endogenous oestrogens (Fig. 1) and their ability to bind to ER have led to significant interest in the potential mechanisms by which phyto-oestrogens may reduce the risk of breast cancer. This stimulated interested in human intervention studies to evaluate the effect of intervention with soya on hormone levels (Cassidy et al. 1994, 1995). These studies showed physiological effects of soya-rich diets on the endocrine regulation of the menstrual cycle and cycle length and led to further investigations which suggested significant effects of soya intervention on urinary oestrogen metabolism (Xu et al. 1998; Duncan et al. 1999, 2000). All of these effects on hormonal regulation and menstrual cycle length may potentially relate to decreased breast cancer risk.

However, to date, there are limited data from human studies to support a protective effect on breast tissue in healthy women. Several human studies have investigated 
the effect of changes in mammographic parenchymal patterns as a biomarker of the effect of isoflavones and soya on breast cancer risk. In one cross-sectional study there was a significant trend towards a higher mammographic density with increasing intake of soya foods in women aged 45-74 years (Jakes et al. 2002). However, two intervention studies, feeding pure isoflavone compounds, showed no significant change in mammographic density when fed either as a $100 \mathrm{mg}$ isoflavone supplement daily over a 1-year period to premenopausal women (Maskarinec et al. 2003) or to older women (aged 45-65 years) fed a red clover supplement for a 1-year period. A recent in vivo examination on the effect of soya intervention (soya protein for 1 year) on breast tissue health in a group of premenopausal women was suggestive of a reduction in fibrocystic disease of the breast (Fleming, 2003), data which require further investigation to determine if soya and its associated isoflavones have a similar beneficial effect in atypia and breast cancer. A recent study showed that red clover extract does not cause any oestrogenic increase in breast density, which would indicate that it is unlikely to cause an increased risk of breast cancer (Powles, 2004).

One of the most contentious issues in phyto-oestrogen research relates to the potential role these compounds play in the prevention of breast cancer and safety of use in women with a history of breast cancer. Several short-term human studies have generated some data of potential concern. In one, consumption of $60 \mathrm{~g}$ soya supplement (45 mg isoflavones) increased the number of breast epithelial cells in a group of premenopausal women, while in another, consumption of a soya protein isolate $(38 \mathrm{mg}$ isoflavones/d) was associated with increased secretion of breast fluid and the appearance of hyperplastic cells (Petrakis et al. 1996; McMichael-Phillips et al. 1998). Both of these observations would be consistent with increased cell proliferation. In isolation these observations pose concern for increased risk of tumour development in women consuming phyto-oestrogen-rich diets, even though this view is not consistent with the epidemiological data. Data from animal models suggest that a life-long diet rich in phyto-oestrogen-rich foods may confer the greatest protective effects, and this increased resistance to developing experimentally induced breast cancer was observed in neonatal and prepubertal rats and also in the offspring of mothers who were fed isoflavones while lactating (Lamartiniere et al. 1995; Lamartiniere, 2002). Unquestionably, further studies are needed to address the potential safety issues, particularly for women who are at high risk for developing breast cancer as the use of a weak oestrogen may hypothetically be harmful to patients after a hormonedependent cancer at the stage of micrometastases.

Particular concerns have been expressed for breast cancer patients taking tamoxifen, the widely prescribed long-term adjuvant treatment for breast cancer, and the potential for isoflavones-containing foods or supplements to interfere with the efficacy of this drug. The available in vitro data on phyto-oestrogens and tamoxifen are confusing and suggest differential effects depending on the concentrations of the two molecules present (Messina \& Loprinzi, 2001). Two animal studies suggest a combination of tamoxifen and genistein enhance the efficacy of the treatment. In a rat model, the combination of genistein and tamoxifen synergistically inhibited the development of mammary cancer while in another rat model system, the combination of tamoxifen and soya reduced tumour development by almost $50 \%$ more than either treatment alone (Messina \& Loprinzi, 2001). Further investigation of such drug-phytooestrogen interaction merits further research.

\section{Endometrial cancer}

Dietary factors may play an important role in explaining the international variability in incidence rates of endometrial cancer which vary more than 10-fold worldwide (Schaffer, 1997). Phytochemicals that elicit oestrogenic effects are of increasing interest in relation to their possible influence on the physiology of the reproductive tract (Wade et al. 2003).

Studies in animals have found that whilst commercially available oestrogen preparations increase uterine weight, the isoflavone genistein has the opposite effect, potentially suggesting that consumption of phyto-oestrogens in the diet would not increase the risk of endometrial cancer. In a nonhuman primate model, treatment with soya protein isolate for 6 months (dose equivalent to $148 \mathrm{mg} / \mathrm{d}$ in man) did not induce proliferation in endometrial tissue (Foth \& Cline, 1998). Epidemiological data are supportive of the animal data, where a study of a group of multi-ethnic women in Hawaii suggested that high soya consumers had a decreased risk of endometrial cancer (Goodman et al. 1997). A recent case-control study also suggested that isoflavone intake was inversely related to risk of endometrial cancer (HornRoss et al. 2003) and this association was stronger in postmenopausal women. However, in another study legume intake was shown to be associated with a slight increase in risk of endometrial cancer in Chinese women (Shu et al. 1991). However, many of these studies were not specifically designed to address the potential role of soya food intake in relation to endometrial cancer risk. A recent populationbased case-control study which was specifically designed to assess the potential role of soya food intake in relation to endometrial cancer risk suggests that habitual consumption of soya foods, measured as either soya protein intake or soya isoflavones, is associated with a significant reduction in risk of endometrial cancer particularly among women with a higher BMI or waist:hip ratio (Xu et al. 2004).

The responsiveness of endometrial genes to phytooestrogens (genistein and daidzein) has been examined in vivo in the rat endometrium with data suggesting that genistein had specific effects on the transcription of a gap junction connexin gene (Cx26; Heikaus et al. 2002). In several reported human intervention studies, with a range of health endpoints, there was no observed effect of soya or phyto-oestrogen supplementation on endometrial histology (Duncan et al. 2000; Scambia et al. 2000; Upmalis et al. 2000; Clifton-Bligh et al. 2001). In addition, several studies specifically investigated the effects of isoflavone consumption on endometrial thickness. In one study, a double-blind randomised placebo-controlled trial conducted in sixty-two postmenopausal women who were fed $72 \mathrm{mg}$ soya isoflavones daily, there was no observed effect on either endometrial thickness or on the pulsatility index of the uterine or cerebral arteries (Penotti et al. 
2003). A smaller intervention in a group of perimenopausal women fed $50 \mathrm{mg}$ red clover extract daily also showed no effect on the endometrium using $\mathrm{Ki}-67$ as a proliferative index biomarker (Hale et al. 2001). However, a recent study examined the effect of soya isoflavones together with oestrogen treatment (fed as soya protein isolate containing $120 \mathrm{mg}$ isoflavones/d for 6 months) and showed that this combined treatment did not protect the endometrium from oestradiol-induced hyperplasia in postmenopausal women (Murray et al. 2003).

\section{Cognition}

It has been known for some time that phyto-oestrogens can cross the blood-brain barrier (Chang et al. 2000; Doerge et al. 2001; Lephart et al. 2002), and in animal models isoflavone stimulated biomarkers important for cognitive function and improved performance on a radial maze task (Lund et al. 2001; Lephart et al. 2002). Therefore the impact of phyto-oestrogens on cognitive performance is currently of significant interest and was recently reviewed (Hill \& Dye, 2003).

Previous data from an epidemiological study suggested a positive association between tofu consumption and cognitive decline in middle-aged Japanese-Americans with a dose-dependent increase of up to $2 \cdot 8$-fold in risk of developing vascular dementia when two to three or more servings of tofu were consumed per week (White et al. 1996). However, although age, education and history of prior stroke explained $27.8 \%$ of the variance in cognitive function test scores, tofu intake only accounted for $0.8 \%$ (White et al. 1996). To date, human intervention studies investigating the effects of phyto-oestrogens on cognitive function have been equivocal; the largest study, a doubleblind randomised placebo-controlled trial in postmenopausal women, observed no effect following a 1-year intervention of $99 \mathrm{mg}$ isoflavones (aglycone equivalents) on a range of measures of cognitive function (KreijkampKaspers et al. 2004). In two other smaller intervention studies in postmenopausal women there was a suggestion of beneficial effects on cognitive function following intervention with soya isoflavone supplements. In one short-term study, postmenopausal women fed $60 \mathrm{mg}$ isoflavones as a soya supplement showed improvements in cognitive performance following the intervention (Duffy et al. 2003). In addition a 6-month study, where $110 \mathrm{mg}$ soya isoflavone supplement (fed as $55 \mathrm{mg}$ twice daily) was fed had favourable effects on cognitive function, particularly verbal memory (Kritz-Silverstein et al. 2003). A small randomised controlled study (soya containing 100 v. $0.5 \mathrm{mg} / \mathrm{d}$ over 10 weeks) was suggestive of a significant influence of isoflavone intake on cognitive function in a group of young volunteers and showed sex differences in cognitive ability (File et al. 2001) but time of day effects on cognitive function were not controlled (Hill \& Dye, 2003).

\section{Menopausal symptoms}

One area of active research relates to the potential for phytooestrogens to alleviate symptoms of the menopause.
The epidemiological observation that there are marked differences in hot flushes in menopausal women in Europe and Asian countries which may relate to their soya exposure, together with data from prospective and crosssectional studies from Japan (Nagata et al. 1999, 2001) suggesting that soya intake is negatively correlated with the number of hot flushes, have resulted in significant research activity. In a case-control study there was a trend towards a decrease in hot flushes with increased intake of isoflavones, although this did not reach statistical significance (Somekawa et al. 2001). However, the lowest quartile of intake ranged up to $35 \mathrm{mg} / \mathrm{d}$ with no comparison of intakes akin to levels of exposure in Europe, and may have been above the threshold necessary to experience benefit.

Numerous short-term studies have attempted to evaluate the effect, using a range of isoflavone supplements, traditional soya foods or isoflavone-enriched soya foods. These intervention studies, conducted in both peri- and postmenopausal women, have generated variable results, but in general isoflavone supplements appear to be relatively ineffective in managing hot flushes, whilst isoflavone-rich foods appear to have a beneficial effect that exceeds that of the placebo (there is a well-established strong placebo effect on menopausal symptoms from HRT studies) but the response is significantly less impressive than the effects observed with HRT (Kang et al. 2002; Kronenberg \& FughBerman, 2002). However, most of the studies have been conducted over a short time scale, used limited endpoint assessment, and did not clearly define the dose administered.

Given the growing interest in alternatives to HRT, and paucity of data on efficacy, several larger-scale studies have recently reported on the effects of isoflavone supplements on menopausal symptom relief. In one, a randomised placebo-controlled study compared the efficacy and safety of two dietary isoflavone supplements made from red clover extract. Symptomatic menopausal women ( $n$ 246; experiencing 8.1 flushes per d) consumed either 82 or $57 \mathrm{mg}$ red clover extract preparations daily for 12 weeks. Although the data showed no significant reduction in hot flush count in either treatment group compared with placebo at 12 weeks, the $82 \mathrm{mg} / \mathrm{d}$ dose did appear to reduce hot flushes more rapidly (Tice et al. 2003). In another multicentre randomised controlled study, $80 \mathrm{mg}$ soya isoflavones daily for 12 weeks had no advantage over placebo on severity of menopausal symptoms, although there was some improvement in psychological symptoms in the group consuming both isoflavones and melatonin (Secreto et al. 2004).

Although together these data suggest that isoflavones do not exert a clinically important effect on hot flushes and other symptoms of menopause, severity of flushes may be an important determinant of efficacy. A meta-analysis of available studies examined the relationship between frequency of hot flushes before study and efficacy of the phyto-oestrogen intervention. These data suggest that hot flush frequency at the beginning of the study explained about $46 \%$ of the treatment effect (Messina \& Hughes, 2003) and suggest that patients with frequent hot flushes may get greater benefit by including soya in their diet. Another area which warrants further research relates to drug interactions with phyto-oestrogens, and one specific area 
that warrants investigation relates to potential interactions with HRT preparations.

Most of the studies that have been performed, however, have been short-term and the question of whether consuming phyto-oestrogen-rich diets before entering the menopause would be more effective is unknown. This is more akin to the Japanese experience, where women have consumed isoflavones for all their fertile years.

\section{Renal health}

Although it is well established that consumption of soya retards the development and progression of chronic renal disease (Ranich et al. 2001; Velasquez \& Bhathena, 2001), it remains unclear if these renal protective effects are related to the protein content, the isoflavone content, a combination of these factors, or some other component of soya.

Dietary intervention studies have shown that consumption of soya-based protein reduces proteinuria and attenuates renal functional or structural damage in animal models and human subjects with various forms of chronic renal disease (Ranich et al. 2001). However, it remains unclear which component or combination of components of soya protein are responsible for these effects. Data from animal studies have shown that soya protein improved peripheral insulin sensitivity and lowered fasting glucose and insulin levels, suggesting a mechanism for renal protection (Lavigne et al. 2000). In addition, the amino acid component of soya, high in arginine and glycine, may induce a low postprandial insulin:glucagon ratio that may be associated with low serum cholesterol (Ranich et al. 2001). The diverse cellular actions of isoflavones lends support to their potential protective effect on renal function (Velasquez \& Bhathena, 2001), including their effects on lipoprotein metabolism (Crouse et al. 1999), and vascular atherosclerosis (Honore et al. 1997). In addition, the observed blood pressure-lowering effect of isoflavones may translate into a reduced glomerular blood flow and hydraulic pressure, and this may offer protection against glomerular injury (Lafferty \& Brenner, 1990). More recently we have observed, using metabonomics technology, that soya isoflavone intervention modifies osmolyte levels in a direction which suggests they may improve glomerular function and kidney function (Solanky et al. 2003).

In human subjects, short-term incorporation of soya protein in the diet ( 3 weeks) has been associated with lower renal plasma flow, glomerular filtration rate and fractional clearance of albumin. In a randomised cross-over study in patients with a variety of nephritic syndromes a soya diet lowered albumin and blood lipid levels (D'Amico \& Gentile, 1993). However, in a study of obese patients with type 2 diabetes, consumption of a soya-based diet for 8 weeks reduced lipoprotein status but had no effect on glomerular filtration rate or proteinuria (Anderson et al. 1998). In several animal studies it has been shown that soya protein preserves glomerular morphology, prevents proteinuria, and prevents glomerular hyperfiltration (Lafferty \& Brenner, 1990; Maddox et al. 2002). More recently in a study with obese Zucker rats it was shown that soya blunted the rate of progression of glomerular injury as evidenced by a delay in the development of proteinuria and significantly less glomerular injury (Maddox et al. 2002).

The long-term effects of soya protein have yet to be fully understood. However, animal studies indicate that chronic soya protein intake preserves the function of damaged kidneys significantly better than animal protein (Ranich et al. 2001). It has been suggested that incorporating soya into the diet may have therapeutic benefits in diseases such as diabetic nephropathy by slowing the deterioration of renal function and decreasing proteinuria.

A recent study in end-stage renal disease patients on dialysis showed that patients who ingested isoflavone-rich diets had higher levels of genistein and daidzein than healthy subjects, and levels remained high for several days due to a lack of renal excretion. The half-life of both compounds was also significantly longer in the end-stage renal disease patients than in healthy subjects (Fanti et al. 1999, 2003). Long-term studies are therefore required to evaluate safety and efficacy of phyto-oestrogens in renal disease progression and in patients with renal failure.

\section{Cardiovascular health}

Epidemiological studies suggest that differences in diet may explain the lower incidence of CVD in Japan compared with other industrialised countries such as the USA or the UK. The high dietary intake of dietary isoflavones is thought to be in part responsible (Cassidy, 1996, 2003; Adlercreutz \& Mazur, 1997; Setchell, 1998). Potential anti-atherogenic effects of isoflavones include a reduction in LDLcholesterol, modulation of pro-inflammatory cytokines, cell-adhesion proteins and NO formation, protection of LDL against oxidation, inhibition of platelet aggregation and an improvement in vascular reactivity (Fig. 2).

Although the hypocholesterolaemic effect of soya has been recognised from animal studies for almost a century (Anderson et al. 1995; Anthony et al. 1996) the relative importance of isoflavones in this mechanism remains a contentious issue and data from a recent meta-analysis suggest the isoflavone component may not be as important as initially thought (Weggemans \& Trautwein, 2003). The effect of soya and its isoflavones on lipoprotein status have been extensively reviewed previously (Demonty et al. 2003; Hermansen et al. 2003). However, any potential beneficial effects on lipid profiles may be only one component of protective responses since isoflavones have also been shown in vitro to inhibit the process of coagulation, improve blood flow, exert anti-inflammatory effects, act as antioxidants, or may exert direct effects on the arterial wall (Cassidy \& Griffin, 1999).

One of the greatest health benefits associated with a high phyto-oestrogen diet may relate to the effects on blood vessels. ER $\beta$ plays an essential role in the regulation of blood pressure and vascular function (Rubanyi et al. 2002; Watanabe et al. 2003), and the presence of equal proportions of ER $\alpha$ and ER $\beta$ in the endothelial wall of blood vessels (Register \& Adams, 1998; Adams et al. 2002) together with the stronger binding affinity of isoflavones to ERß (Kuiper et al. 1997) support this hypothesis. Impaired endothelial function is associated with hypertension, dyslipidaemia and diabetes 
in women (Sader \& Celermajer, 2002) and is considered to be an important predictor of the risk of cardiovascular events (Halcox et al. 2002). Animal data suggest that isoflavones increase blood vessel dilatation and improve blood flow in rhesus monkeys (Honore et al. 1997; Williams \& Clarkson, 1998). More recently, studies on the effects of isoflavones, from soya foods and supplements, on vascular function have been conducted, with available data on effects on blood pressure and endothelial function reviewed in Tables 1 and 2 (Hodgson et al. 1999; Nestel et al. 1999; Washburn et al. 1999; Simons et al. 2000; Vigna et al. 2000; Hermansen et al. 2001; Teede et al. 2001, 2003; Yildirir et al. 2001; Bloedon et al. 2002; Chiechi et al. 2002; Hale et al. 2002; Jayagopal et al. 2002; Jenkins et al. 2002; Rivas et al. 2002; Blum et al. 2003; Cuevas et al. 2003; Howes et al. 2003; Steinberg et al. 2003).

Dietary supplementation with soya which has a high content of isoflavones appears to reduce blood pressure in both men and postmenopausal women (Table 1), particularly when consumed from soya sources. Several studies have examined the effects on isoflavones from red clover on blood pressure, and only one reported improvements in postmenopausal women with type 2 diabetes (Table 1).
The available data on the effects of isoflavones on endothelial function are equivocal, with four studies suggesting no effect, while five have reported an improvement in endothelial function (Table 2).

Further studies are required to elucidate the relative importance of isoflavones on vascular function and importantly to address effects on more robust morbidity and mortality endpoints. However, recent data showing an effect of isoflavones (from red clover) on arterial stiffness (Teede et al. 2003), which is considered to be predictive of future cardiovascular events (van Popele et al. 2001; Boutouyrie et al. 2002), suggest that this is an important area for future research.

\section{Bone health}

Although data from rodent studies clearly demonstrate that soya isoflavones are effective in reducing bone loss and increasing bone formation, two long-term studies using ovarectomised monkeys have failed to show an effect of soya isoflavones on bone (Anderson \& Garner, 1998). It is possible that the responsiveness to bone may differ between species as it is well established that there are significant

Table 1. Effects of isoflavones on blood pressure

\begin{tabular}{|c|c|c|c|c|c|}
\hline Reference & Study design & Sex & $\begin{array}{l}\text { Duration } \\
\text { (months) }\end{array}$ & $\begin{array}{l}\text { Isoflavone source } \\
\text { and dose }(\mathrm{mg} / \mathrm{d})\end{array}$ & $\begin{array}{l}\text { Change of } \\
\text { SBP and DBP } \\
\text { following } \\
\text { intervention } \\
(\mathrm{mmHg})\end{array}$ \\
\hline Bloedon et al. (2002) & Single dose ( $n$ 24) & $\begin{array}{l}\text { Women, } \\
\text { postmenopausal }\end{array}$ & $1 d$ & $\begin{array}{l}\text { Supplement: } \\
2,4,8 \text { or } 16\end{array}$ & $-16 /-13$ \\
\hline Chiechi et al. (2002) & Parallel group (n 187) & $\begin{array}{l}\text { Women, } \\
\text { postmenopausal }\end{array}$ & 6 & Soya foods: 47 & $-3 / 0$ \\
\hline Hale et al. (2002) & Parallel group ( $n$ 29) & $\begin{array}{l}\text { Women, } \\
\text { postmenopausal }\end{array}$ & 0.5 & $\begin{array}{l}\text { Soya isoflavone } \\
\text { concentrate: } 80\end{array}$ & $\mathrm{NC}$ \\
\hline Hodgson et al. (1999) & $\begin{array}{l}\text { Placebo-controlled } \\
\text { cross-over }(n 59)\end{array}$ & Mixed & 2 & $\begin{array}{l}\text { Supplement } \\
\text { (red clover): } 55\end{array}$ & $\mathrm{NC}$ \\
\hline Jayagopal et al. (2002) & $\begin{array}{l}\text { Placebo-controlled } \\
\text { cross-over ( } n 32), \\
\text { type } 2 \text { diabetics }\end{array}$ & $\begin{array}{l}\text { Women, } \\
\text { postmenopausal }\end{array}$ & 3 & Soya protein: 132 & $-2 /-1$ \\
\hline Jenkins et al. (2002) & $\begin{array}{l}\text { Placebo-controlled } \\
\text { cross-over }(n 41) \\
\text { hyperlipidaemic }\end{array}$ & Mixed & 1 & Soya protein: 10, 73 & $\mathrm{NC}$ \\
\hline Nestel et al. (1999) & $\begin{array}{l}\text { Placebo-controlled } \\
\text { cross-over }(n 21)\end{array}$ & Women & 1 & Supplement: 80 & $\mathrm{NC}$ \\
\hline Rivas et al. (2002) & $\begin{array}{l}\text { Parallel group ( } n 40) \text {, } \\
\text { hypertensive }\end{array}$ & Mixed & 3 & Soya milk: 143 & $-18 /-16$ \\
\hline Simons et al. (2000) & $\begin{array}{l}\text { Placebo-controlled } \\
\text { cross-over (n 20) }\end{array}$ & $\begin{array}{l}\text { Women, } \\
\text { postmenopausal }\end{array}$ & 2 & Supplement: 80 & $\mathrm{NC}$ \\
\hline Teede et al. (2001) & Parallel group (n 179) & Mixed & 3 & $\begin{array}{l}\text { Soya protein } \\
\text { isolate: } 118\end{array}$ & $-3 \cdot 9 /-2 \cdot 4$ \\
\hline Vigna et al. (2000) & Parallel group ( $n 77$ ) & $\begin{array}{l}\text { Women, } \\
\text { postmenopausal }\end{array}$ & 3 & 76 & $-3 / 0$ \\
\hline Washburn et al. (1999) & $\begin{array}{l}\text { Placebo-controlled } \\
\text { cross-over }(n 51)\end{array}$ & $\begin{array}{l}\text { Women, } \\
\text { perimenopausal }\end{array}$ & 1.5 & Soya protein: 34 & $0 /-5$ \\
\hline Howes et al. (2003) & $\begin{array}{l}\text { Placebo-controlled } \\
\text { cross-over }(n 16) \\
\text { type } 2 \text { diabetics }\end{array}$ & $\begin{array}{l}\text { Women, } \\
\text { postmenopausal }\end{array}$ & 4 & $\begin{array}{l}\text { Supplements } \\
\quad \text { (red clover): } 50\end{array}$ & $-3 \cdot 7 /-1.5$ \\
\hline Teede et al. (2003) & Placebo-controlled ( $n$ 80) & Mixed & 1.5 & $\begin{array}{l}\text { Supplements } \\
\text { (red clover): } 80\end{array}$ & $\mathrm{NC}$ \\
\hline
\end{tabular}

SBP, systolic blood pressure; DBP, diastolic blood pressure; NC, not changed. 
Table 2. Effects of isoflavones on endothelial function

\begin{tabular}{|c|c|c|c|c|c|}
\hline Reference & Study design & Sex & $\begin{array}{l}\text { Duration } \\
\text { (months) }\end{array}$ & $\begin{array}{l}\text { Isoflavone source } \\
\text { and dose }(\mathrm{mg} / \mathrm{d})\end{array}$ & $\begin{array}{l}\text { Endothelial } \\
\text { function }\end{array}$ \\
\hline Simons et al. (2000) & $\begin{array}{l}\text { Double-blind placebo- } \\
\text { controlled }(n 20)\end{array}$ & $\begin{array}{l}\text { Women, } \\
\text { postmenopausal }\end{array}$ & 2 & Supplement: 80 & No effect \\
\hline Teede et al. (2001) & $\begin{array}{l}\text { Double-blind placebo- } \\
\text { controlled }(n 179)\end{array}$ & Mixed & 3 & Soya protein isolate: 54 & No effect \\
\hline Yildirir et al. (2001) & $\begin{array}{l}\text { Hypercholesterolaemic } \\
\text { (n 20) }\end{array}$ & Men & 1.5 & Soya protein & Improvement \\
\hline Hale et al. (2002) & Placebo-controlled (n 29) & $\begin{array}{l}\text { Women, } \\
\text { postmenopausal }\end{array}$ & 0.5 & $\begin{array}{l}\text { Soya isoflavone } \\
\text { concentrate: } 80\end{array}$ & No effect \\
\hline Blum et al. (2003) & $\begin{array}{l}\text { Double-blind placebo- } \\
\text { controlled ( } n 24), \\
\text { hypercholesterolaemic }\end{array}$ & $\begin{array}{l}\text { Women, } \\
\text { postmenopausal }\end{array}$ & 1.5 & Soya protein supplement: 85 & No effect \\
\hline Steinberg et al. (2003) & $\begin{array}{l}\text { Double-blind cross-over } \\
\text { ( }(n 28)\end{array}$ & $\begin{array}{l}\text { Women, } \\
\text { postmenopausal }\end{array}$ & 1.5 & Soya protein: 2 and 107 & Improvement \\
\hline Howes et al. (2003) & $\begin{array}{l}\text { Double-blind placebo- } \\
\text { controlled cross-over } \\
\text { (n 16), type } 2 \text { diabetics }\end{array}$ & $\begin{array}{l}\text { Women, } \\
\text { postmenopausal }\end{array}$ & 4 & $\begin{array}{l}\text { Supplements (red clover): } \\
\quad 50\end{array}$ & Improvement \\
\hline Teede et al. (2003) & $\begin{array}{l}\text { Double-blind placebo- } \\
\text { controlled }(n 80)\end{array}$ & Mixed & 1.5 & $\begin{array}{l}\text { Supplements (red clover): } \\
\quad 80\end{array}$ & Improvement \\
\hline Cuevas et al. (2003) & $\begin{array}{l}\text { Double-blind } \\
\text { cross-over ( } n \text { 18), } \\
\text { hypercholesterolaemic }\end{array}$ & $\begin{array}{l}\text { Women, } \\
\text { postmenopausal }\end{array}$ & 1 & Soya protein isolate & Improvement \\
\hline
\end{tabular}

species differences in the metabolic handling of isoflavones (Lundh, 1995; Latonnelle et al. 2002).

Epidemiological evidence is supportive of a role for isoflavones in preventing bone loss since the incidence of hip fractures is lower in Asia than in most Western communities (Tobias et al. 1994). However, these differences in osteoporosis-related fractures may be accounted for by other factors including, for example, skeletal size (Cummings et al. 1994; Ho, 1996). To date the available data from observational studies and shortterm intervention trials have produced variable results, and evaluation of the existing data is complex given the differences in study designs, sources of isoflavones, dose administered and endpoints measured. The human data have recently been reviewed (Branca, 2003; Setchell \& Lydeking-Olsen, 2003) and a summary of available data is shown in Table 3 (Murkies et al. 1995; Dalais et al. 1998; Potter et al. 1998; Alekel et al. 2000; Scambia et al. 2000; Upmalis et al. 2000; Wangen et al. 2000; Arjmandi, 2001; Clifton-Bligh et al. 2001; Hsu et al. 2001; Scheiber et al. 2001; Anderson et al. 2002; Chiechi et al. 2002; Morabito et al. 2002; Uesugi et al. 2002; Chen et al. 2003; Atkinson et al. 2004; Brooks et al. 2004; Gallagher et al. 2004; Lydeking-Olsen et al. 2004). These available data suggest that when soya foods containing significant levels of isoflavones are substituted in the diet of postmenopausal women, bone resorption is reduced (Branca, 2003; Setchell \& Lydeking-Olsen, 2003). There also appears to be a threshold of intake required for a measurable change in bone mineral density. These data are suggestive of beneficial effects on biochemical markers of bone turnover; however, whether these data translate into long-term effects on bone density or, more importantly, fracture risk remains to be established. More long-term studies are therefore required, with fracture as an endpoint measure to determine effective doses and relative importance of isoflavones for potentially preventing osteoporosis.

\section{Skin ageing}

Interest in the potential anti-photocarcinogenic and antiphotoageing effects of isoflavones has been emerging predominantly in relation to topical application of the phyto-oestrogens and, more recently, in relation to potential skin benefits following the ingestion of isoflavones (Wei et al. 2003). Numerous in vitro mechanisms of action including protection from oxidative and photodynamically damaged DNA, down regulation of UVB-activated signal transduction cascades and antioxidant activities suggest in particular that the isoflavone genistein has potential anti-cancer properties (Wei et al. 2003). Genistein significantly suppressed UV light-induced oxidative DNA damage in purified DNA and cultured cells and inhibited UVB-induced c-fos and c-jun proto-oncogene expression in mouse skin.

In addition, data from animal experiments suggest that genistein, administered either topically or orally, inhibits skin carcinogenesis and cutaneous ageing induced by UV light in mice and photodamage in man (Wei et al. 2003). Topical application of genistein protects the skin from photodamage by inhibiting UVB-induced acute and chronic photodamage in mouse skin (Shyong et al. 2002; Wei et al. 2003). In human subjects, topical administration of genistein before UV exposure also protected human skin against UVBinduced photodamage (Wei et al. 2003). The skin naturally uses antioxidants to protect it from photodamage and topical use of isoflavones may favourably supplement sunscreen protection and provide an additional anticarcinogenic protection (Pinnell, 2003). Further studies are required in human subjects to elucidate the potential protective effect of isoflavones on skin health following the ingestion of isoflavones rather than topical application.

\section{Safety issues}

It is inevitable that advocating the increased consumption of compounds that have the potential to exert 'oestrogenic' 


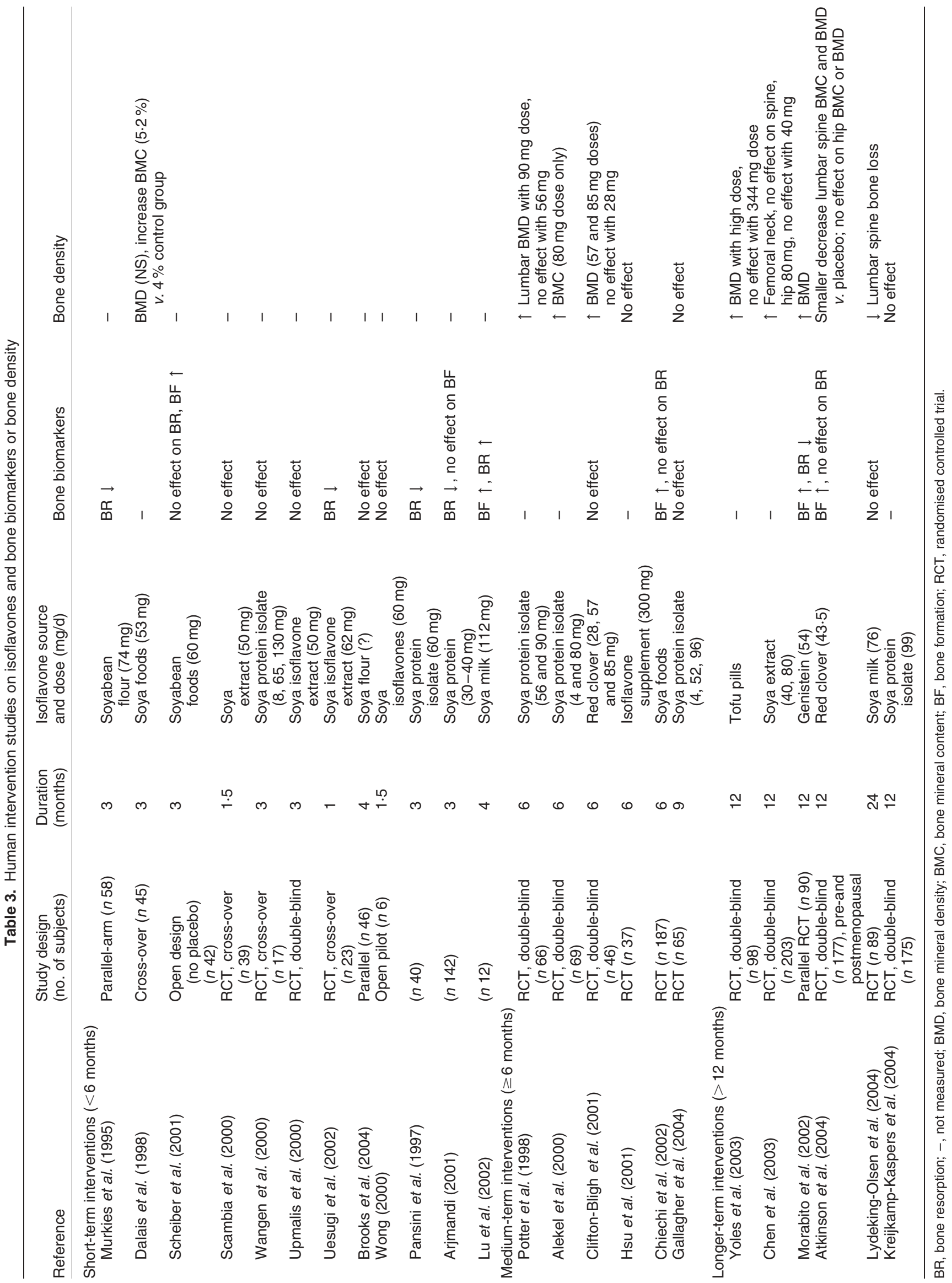


effects would raise issues of safety. Phyto-oestrogens are multifaceted compounds, and only one of a series of their potential mechanisms relates to their weak oestrogenic nature. Substantial literature on the potential genotoxicity, carcinogenicity, reproductive and development toxicity of soya isoflavones exists and has recently been reviewed (Munro et al. 2003). However, the extrapolation of such animal and in vitro data to human exposure data remains difficult to interpret.

Numerous dietary intervention studies have been conducted in men, premenopausal and postmenopausal women, in which a range of isoflavone-rich foods or supplements have been ingested. Duration of exposure has ranged from 1 month to 6 months with intakes of between 3 and $131 \mathrm{mg}$ aglycone equivalents/d (Gooderham et al. 1996; Baum et al. 1998; Crouse et al. 1999; Samman et al. 1999; Dewell et al. 2002; Munro et al. 2003). In these human intervention studies no adverse effects have been reported. These data provide supportive evidence for the safety of chronic intake of isoflavones at this level of expsoure. However, it is critical that markers of potential adverse effects are monitored in human clinical trials addressing the hypothetical benefits of these compounds in sub-groups of the population.

Although no clinical studies have to date examined the effect of the combined treatment of HRT and isoflavones, data from non-human primate studies suggest that it does not produce adverse effects. In ovarectomised non-human primates a combination of HRT and soya isoflavones produced a greater decrease in cardiovascular risk factors than either HRT or soya isoflavone alone (Wagner et al. 1997). In studies on ovarectomised macaque monkeys, soya protein isolate in combination with oestradiol did not increase uterine weight, nor did it affect a range of morphometric, histopathological or immunohistochemical parameters measured in mammary gland and endometrial tissues over a 6-month intervention (Foth \& Cline, 1998). This was in contrast to the effects observed with oestradiol alone.

Assessment of safety is a critical element in the design of future studies, in particular addressing the effects of high levels of intake following long-term exposure.

\section{Summary}

Studies conducted to date in human subjects clearly confirm that isoflavones can exert hormonal effects. These effects may be of benefit in the prevention of many of the common diseases and conditions observed in Western populations (such as breast cancer, menopausal symptoms, osteoporosis and CVD) where the diet is typically devoid of these biologically active naturally occurring compounds. However, inter-comparisons of available data are difficult given the wide range of food products, supplements and doses used in existing studies. In addition, biological effects are potentially dependent on many factors including dose, duration of use, metabolism and intrinsic oestrogenic state, and many of the available studies are short term and rely on intermediate biomarkers as endpoint measures rather than 'hard' disease endpoints. There is a great need for long-term prospective studies and clinical trials to derive empirical proof of the efficacy and safety of isoflavones and to fully explore their potential role in preventative medicine.

\section{References}

Adams MR, Golden DL, Register TC, Anthony MS, Hodgin JB, Maeda N \& Williams JK (2002) The atheroprotective effect of dietary soy isoflavones in apolipoprotein E-/- mice requires the presence of estrogen receptor-alpha. Arteriosclerosis, Thrombosis and Vascular Biology 22, 1859-1864.

Adlercreutz H, Fotsis T, Bannwart C, Wahala K, Makela T, Brunow $\mathrm{G} \&$ \& Hase $\mathrm{T}$ (1986) Determination of urinary lignans and phytoestrogen metabolites, potential antiestrogens and anticarcinogens, in urine of women on various habitual diets. Journal of Steroid Biochemistry 25, 791-797.

Adlercreutz H, Fotsis T, Setchell K \& Axelson M (1981) Effect of diet and antibiotics on urinary-excretion of lignans. Journal of Clinical Chemistry and Clinical Biochemistry 19, 597.

Adlercreutz H \& Mazur W (1997) Phyto-oestrogens and Western diseases. Annals of Medicine 29, 95-120.

Akiyama T, Ishida J, Nakagawa S, Ogawara H, Watanabe S, Itoh N, Shibuya M \& Fukami Y (1987) Genistein, a specific inhibitor of tyrosine-specific protein kinases. Journal of Biological Chemistry 262, 5592-5595.

Alekel DL, Germain AS, Peterson CT, Hanson KB, Stewart JW \& Toda T (2000) Isoflavone-rich soy protein isolate attenuates bone loss in the lumbar spine of perimenopausal women. American Journal of Clinical Nutrition 72, 844-852.

An JP, Tzagarakis-Foster C, Scharschmidt TC, Lomri N \& Leitman DC (2001) Estrogen receptor beta-selective transcriptional activity and recruitment of coregulators by phytoestrogens. Journal of Biological Chemistry 276, 17808-17814.

Anderson JJ, Chen X, Boass A, Symons M, Kohlmeier M, Renner JB \& Garner SC (2002) Soy isoflavones: no effects on bone mineral content and bone mineral density in healthy, menstruating young adult women after one year. Journal of the American College of Nutrition 21, 388-393.

Anderson JJ \& Garner SC (1998) Phytoestrogens and bone. Baillieres Clinical Endocrinology and Metabolism 12, 543-557.

Anderson JW, Diwadkar VA \& Bridges SR (1998) Selective effects of different antioxidants on oxidation of lipoproteins from rats. Proceedings of the Society for Experimental Biology and Medicine 218, 376-381.

Anderson JW, Johnstone BM \& Cooknewell ME (1995) Metaanalysis of the effects of soy protein-intake on serumlipids. New England Journal of Medicine 333, 276-282.

Anthony MS, Clarkson TB, Hughes CL Jr, Morgan TM \& Burke GL (1996) Soybean isoflavones improve cardiovascular risk factors without affecting the reproductive system of peripubertal rhesus monkeys. Journal of Nutrition 126, 43-50.

Arjmandi BH (2001) The role of phytoestrogens in the prevention and treatment of osteoporosis in ovarian hormone deficiency. Journal of the American College of Nutrition 20, 398S-402S.

Arora A, Nair MG \& Strasburg GM (1998) Antioxidant activities of isoflavones and their biological metabolites in a liposomal system. Archives of Biochemistry and Biophysics 356, 133-141.

Atkinson C, Compston JE, Day NE, Dowsett M \& Bingham SA (2004) The effects of phytoestrogen isoflavones on bone density in women: a double-blind, randomized, placebo-controlled trial. American Journal of Clinical Nutrition 79, 326-333.

Atkinson C, Frankenfeld CL \& Lampe JW (2005) Gut bacterial metabolism of the soy isoflavone daidzein: exploring the relevance to human health. Experimetal Biology and Medicine 230, 155-170. 
Axelson M, Kirk DN, Farrant RD, Cooley G, Lawson AM \& Setchell KDR (1982) The identification of the weak estrogen equol 7-hydroxy-3-(4'- hydroxyphenyl)chroman in humanurine. Biochemical Journal 201, 353-357.

Axelson M, Sjovall J, Gustafsson BE \& Setchell KDR (1984) Soya - a dietary source of the non-steroidal estrogen equol in man and animals. Journal of Endocrinology 102, 49-56.

Banks E, Beral V, Bull D, Reeves G, Austoker J, English R, Patnick J, Peto R, Vessey M, Wallis M, Abbott S, Bailey E, et al. (2003) Breast cancer and hormone-replacement therapy in the Million Women Study. Lancet 362, 419-427.

Bannwart C, Fotsis T, Heikkinen R \& Adlercreutz H (1984) Identification of the isoflavonic phytoestrogen daidzein in human urine. Clinica Chimica Acta 136, 165-172.

Barnes S (1998) Phytoestrogens and breast cancer. Baillieres Clinical Endocrinology and Metabolism 12, 559-579.

Barnes S, Kim H, Darley-Usmar V, Patel R, Xu J, Boersma B \& Luo M (2000) Beyond ERalpha and ERbeta: estrogen receptor binding is only part of the isoflavone story. Journal of Nutrition 130, 656S-657S.

Baum JA, Teng HY, Erdman JW, Weigel RM, Klein BP, Persky VW, Freels S, Surya P, Bakhit RM, Ramos E, Shay NF \& Potter SM (1998) Long-term intake of soy protein improves blood lipid profiles and increases mononuclear cell low-density-lipoprotein receptor messenger RNA in hypercholesterolemic, postmenopausal women. American Journal of Clinical Nutrition 68, $545-551$.

Beecher GR, Bhagwat S, Holden JM, Haytowitz D \& Murphy PA (1999) Isoflavone database for foods. FASEB Journal 13, A885.

Bennetts H, Underwood E \& Shier F (1946) A specific breeding problem of sheep in subterranean clover pastures in Western Australia. Australian Veterinary Journal 22, 2-12.

Bloedon LT, Jeffcoat AR, Lopaczynski W, Schell MJ, Black TM, Dix KJ, Thomas BF, Albright C, Busby MG, Crowell JA \& Zeisel SH (2002) Safety and pharmacokinetics of purified soy isoflavones: single-dose administration to postmenopausal women. American Journal of Clinical Nutrition 76, 1126-1137.

Blum A, Lang N, Vigder F, Israeli P, Gumanovsky M, Lupovitz S, Elgazi A, Peleg A \& Moshe BA (2003) Effects of soy protein on endothelium-dependent vasodilatation and lipid profile in postmenopausal women with mild hypercholesterolemia. Clinical and Investigative Medicine - Medecine Clinique et Experimentale 26, 20-26.

Boutouyrie P, Tropeano AI, Asmar R, Gautier I, Benetos A, Lacolley P \& Laurent S (2002) Aortic stiffness is an independent predictor of primary coronary events in hypertensive patients a longitudinal study. Hypertension 39, 10-15.

Branca F (2003) Dietary phyto-oestrogens and bone health. Proceedings of the Nutrition Society 62, 877-887.

Brooks JD, Ward WE, Lewis JE, Hilditch J, Nickell L, Wong E \& Thompson LU (2004) Supplementation with flaxseed alters estrogen metabolism in postmenopausal women to a greater extent than does supplementation with an equal amount of soy. American Journal of Clinical Nutrition 79, 318-325.

Cassidy A (2003) Potential risks and benefits of phytoestrogen-rich diets. International Journal for Vitamin and Nutritional Research 73, 120-126.

Cassidy A (1996) Physiological effects of phyto-oestrogens in relation to cancer and other human health risks. Proceedings of the Nutrition Society 55, 399-417.

Cassidy A, Bingham S \& Setchell K (1995) Biological effects of isoflavones in young women: importance of the chemical composition of soyabean products. British Journal of Nutrition 74, 587-601.

Cassidy A, Bingham S \& Setchell KD (1994) Biological effects of a diet of soya protein rich in isoflavones on the menstrual cycle of premenopausal women. American Journal of Clinical Nutrition 60, 333-340.

Cassidy A \& Faughnan M (2000) Phyto-oestrogens through the life cycle. Proceedings of the Nutrition Society 59, 489-496.

Cassidy A \& Griffin B (1999) Phyto-oestrogens: a potential role in the prevention of CHD? Proceedings of the Nutrition Society 58, $193-199$.

Chang HC, Churchwell MI, Delclos KB, Newbold RR \& Doerge DR (2000) Mass spectrometric determination of Genistein tissue distribution in diet-exposed Sprague-Dawley rats. Journal of Nutrition 130, 1963-1970.

Chen XW, Garner SC, Quarles LD \& Anderson JJB (2003) Effects of genistein on expression cell of bone markers during MC3T3E1 osteoblastic differentiation. Journal of Nutritional Biochemistry 14, 342-349.

Chen Z, Zheng W, Custer LJ, Dai Q, Shu XO, Jin F \& Franke AA (1999) Usual dietary consumption of soy foods and its correlation with the excretion rate of isoflavonoids in overnight urine samples among Chinese women in Shanghai. Nutrition and Cancer 33, 82-87.

Chiechi LM, Secreto G, Vimercati A, Greco P, Venturelli E, Pansini F, Fanelli M, Loizzi P \& Selvaggi L (2002) The effects of a soy rich diet on serum lipids: the Menfis randomized trial. Maturitas 41, 97-104.

Clemons M \& Goss P (2001) Mechanisms of disease - estrogen and the risk of breast cancer. New England Journal of Medicine 344, 276-285.

Clifton-Bligh PB, Baber RJ, Fulcher GR, Nery ML \& Moreton T (2001) The effect of isoflavones extracted from red clover (Rimostil) on lipid and bone metabolism. Menopause 8, 259-265.

Couse JF, Lindzey J, Grandien K, Gustafsson JA \& Korach KS (1997) Tissue distribution and quantitative analysis of estrogen receptor-alpha (ER alpha) and estrogen receptor-beta (ER beta) messenger ribonucleic acid in the wild-type and ER alphaknockout mouse. Endocrinology 138, 4613-4621.

Coward L, Barnes NC, Setchell KDR \& Barnes S (1993) Genistein, daidzein, and their beta-glycoside conjugates - antitumor isoflavones in soybean foods from American and Asian diets. Journal of Agricultural and Food Chemistry 41, 1961-1967.

Crouse JR III, Morgan T, Terry JG, Ellis J, Vitolins M \& Burke GL (1999) A randomized trial comparing the effect of casein with that of soy protein containing varying amounts of isoflavones on plasma concentrations of lipids and lipoproteins. Archives of Internal Medicine 159, 2070-2076.

Cuevas AM, Irribarra VL, Castillo OA, Yanez MD \& Germain A (2003) Isolated soy protein improves endothelial function in postmenopausal hypercholesterolemic women. European Journal of Clinical Nutrition 57, 889-894.

Cummings SR, Cauley JA, Palermo L, Ross PD, Wasnich RD, Black D \& Faulkner KG (1994) Racial-differences in hip axis lengths might explain racial-differences in rates of hip fracture. Osteoporosis International 4, 226-229.

Dalais FS, Rice GE, Wahlqvist ML, Grehan M, Murkies AL, Medley G, Ayton R \& Strauss BJ (1998) Effects of dietary phytoestrogens in postmenopausal women. Climacteric $\mathbf{1}$, $124-129$.

D'Amico G \& Gentile MG (1993) Influence of diet on lipid abnormalities in human renal disease. American Journal of Kidney Diseases 22, 151-157.

Davis JN, Kucuk O, Djuric Z \& Sarkar FH (2001) Soy isoflavone supplementation in healthy men prevents NF-kappa B activation by TNF-alpha in blood lymphocytes. Free Radical Biology and Medicine 30, 1293-1302.

Demonty I, Lamarche B \& Jones PJ (2003) Role of isoflavones in the hypocholesterolemic effect of soy. Nutrition Reviews 61, 189-203. 
Dewell A, Hollenbeck CB \& Bruce B (2002) The effects of soyderived phytoestrogens on serum lipids and lipoproteins in moderately hypercholesterolemic postmenopausal women. Journal of Clinical Endocrinology and Metabolism 87, $118-121$.

Djuric Z, Chen G, Doerge DR, Heilbrun LK \& Kucuk O (2001) Effect of soy isoflavone supplementation on markers of oxidative stress in men and women. Cancer Letters 172, 1-6.

Doerge DR, Churchwell MI, Chang HC, Newbold RR \& Delclos $\mathrm{KB}$ (2001) Placental transfer of the soy isoflavone genistein following dietary and gavage administration to Sprague Dawley rats. Reproductive Toxicology 15, 105-110.

Duffy R, Wiseman H \& File SE (2003) Improved cognitive function in postmenopausal women after 12 weeks of consumption of a soya extract containing isoflavones. Pharmacology, Biochemistry and Behavior 75, 721-729.

Duncan AM, Merz BE, Xu X, Nagel TC, Phipps WR \& Kurzer MS (1999) Soy isoflavones exert modest hormonal effects in premenopausal women. Journal of Clinical Endocrinology and Metabolism 84, 192-197.

Duncan AM, Merz-Demlow BE, Xu X, Phipps WR \& Kurzer MS (2000) Premenopausal equol excretors show plasma hormone profiles associated with lowered risk of breast cancer. Cancer Epidemiology, Biomarkers and Prevention 9, 581-586.

Fanti P, Sawaya BP, Custer LJ \& Franke AA (1999) Serum levels and metabolic clearance of the isoflavones genistein and daidzein in hemodialysis patients. Journal of the American Society of Nephrology 10, 864-871.

Fanti P, Stephenson TJ, Kaariainen IM, Rezkalla B, Tsukamoto Y, Morishita T, Nomura M, Kitiyakara C, Custer LJ \& Franke AA (2003) Serum isoflavones and soya food intake in Japanese, Thai and American end-stage renal disease patients on chronic haemodialysis. Nephrology Dialysis Transplantation 18, $1862-1868$.

Faughnan MS, Hawdon A, Ah-Singh E, Brown J, Millward DJ \& Cassidy A (2004) Urinary isoflavone kinetics: the effect of age, gender, food matrix and chemical composition. British Journal of Nutrition 91, 567-574.

File SE, Jarrett N, Fluck E, Duffy R, Casey K \& Wiseman H (2001) Eating soya improves human memory. Psychopharmacology 157, 430-436.

Fleming R (2003) What effect, if any, does soy protein have on breast tissue? Integrative Cancer Therapies 2, 225-228.

Foth D \& Cline JM (1998) Effects of mammalian and plant estrogens on mammary glands and uteri of macaques. American Journal of Clinical Nutrition 68, 1413S-1417S

Frankenfeld CL, Atkinson C, Thomas WK, Goode EL, Gonzalez A, Jokela T, Wahala K, Schwartz SM, Li SS \& Lampe JW (2004) Familial correlations, segregation analysis, and nongenetic correlates of soy isoflavone-metabolizing phenotypes. Advances in Experimental Medicine and Biology 229, 902-913.

Gallagher JC, Satpathy R, Rafferty K \& Haynatzka V (2004) The effect of soy protein isolate on bone metabolism. Menopause the Journal of the North American Menopause Society 11, 290-298.

Gooderham MH, Adlercreutz H, Ojala ST, Wahala K \& Holub BJ (1996) A soy protein isolate rich in genistein and daidzein and its effects on plasma isoflavone concentrations, platelet aggregation, blood lipids and fatty acid composition of plasma phospholipid in normal men. Journal of Nutrition 126, 2000-2006.

Goodman MT, Wilkens LR, Hankin JH, Lyu LC, Wu AH \& Kolonel LN (1997) Association of soy and fiber consumption with the risk of endometrial cancer. American Journal of Epidemiology 146, 294-306.

Guo TL, White KL Jr, Brown RD, Delclos KB, Newbold RR, Weis C, Germolec DR \& McCay JA (2002a) Genistein modulates splenic natural killer cell activity, antibody-forming cell response, and phenotypic marker expression in $\mathrm{F}(0)$ and $\mathrm{F}(1)$ generations of Sprague-Dawley rats. Toxicology and Applied Pharmacology 181, 219-227.

Guo TL, Zhang XL, Bartolucci E, McCay JA, White KL Jr \& You L (2002b) Genistein and methoxychlor modulate the activity of natural killer cells and the expression of phenotypic markers by thymocytes and splenocytes in F0 and F1 generations of Sprague-Dawley rats. Toxicology 172, 205-215.

Halcox JP, Schenke WH, Zalos G, Mincemoyer R, Prasad A, Waclawiw MA, Nour KR \& Quyyumi AA (2002) Prognostic value of coronary vascular endothelial dysfunction. Circulation 106, 653-658.

Hale G, Paul-Labrador M, Dwyer JH \& Merz CN (2002) Isoflavone supplementation and endothelial function in menopausal women. Clinical Endocrinology 56, 693-701.

Hale GE, Hughes CL, Robboy SJ, Agarwal SK \& Bievre M (2001) A double-blind randomized study on the effects of red clover isoflavones on the endometrium. Menopause 8, 338-346.

Heikaus S, Winterhager E, Traub O \& Grummer R (2002) Responsiveness of endometrial genes Connexin26, Connexin43, $\mathrm{C} 3$ and clusterin to primary estrogen, selective estrogen receptor modulators, phyto- and xenoestrogens. Journal of Molecular Endocrinology 29, 239-249.

Hermansen K, Dinesen B, Hoie LH, Morgenstern E \& Gruenwald J (2003) Effects of soy and other natural products on LDL: HDL ratio and other lipid parameters: a literature review. Advances in Therapy 20, 50-78.

Hermansen K, Sondergaard M, Hoie L, Carstensen M \& Brock B (2001) Beneficial effects of a soy-based dietary supplement on lipid levels and cardiovascular risk markers in type 2 diabetic subjects. Diabetes Care 24, 228-233.

Hill CE \& Dye L (2003) Phytoestrogens and cognitive performance: a review of the evidence. Current Topics in Nutraceutical Research 1, 203-212.

Ho SC (1996) Body measurements, bone mass, and fractures does the East differ from the West? Clinical Orthopaedics and Related Research 323, 75-80.

Hodgson JM, Croft KD, Puddey IB, Mori TA \& Beilin LJ (1996) Soybean isoflavonoids and their metabolic products inhibit in vitro lipoprotein oxidation in serum. Journal of Nutritional Biochemistry 7, 664-669.

Hodgson JM, Puddey IB, Croft KD, Mori TA, Rivera J \& Beilin LJ (1999) Isoflavonoids do not inhibit in vivo lipid peroxidation in subjects with high-normal blood pressure. Atherosclerosis $\mathbf{1 4 5}$, $167-172$.

Honore EK, Williams JK, Anthony MS \& Clarkson TB (1997) Soya isoflavones enhance coronary vascular reactivity in atherosclerotic female macaques. Fertility and Sterility 67, $148-154$.

Horn-Ross PL, John EM, Canchola AJ, Stewart SL \& Lee MM (2003) Phytoestrogen intake and endometrial cancer risk. Journal of the National Cancer Institute 95, 1158-1164.

Howes JB, Tran D, Brillante D \& Howes LG (2003) Effects of dietary supplementation with isoflavones from red clover on ambulatory blood pressure and endothelial function in postmenopausal type 2 diabetes. Diabetes, Obesity and Metabolism 5, 325-332.

Hsu CS, Shen WW, Hsueh YM \& Yeh SL (2001) Soya isoflavone supplementation in postmenopausal women. Effects on plasma lipids, antioxidant enzyme activities and bone density. Journal of Reproductive Medicine 46, 221-226.

Hutchins AM, Lampe JW, Martini MC, Campbell DR \& Slavin JL (1995) Vegetables, fruits, and legumes: effect on urinary isoflavonoid phytoestrogen and lignan excretion. Journal of American Dietetic Association 95, 769-774. 
Ibrahim AR \& Abulhajj YJ (1990) Aromatase inhibition by flavonoids. Journal of Steroid Biochemistry and Molecular Biology 37, 257-260.

Izumi T, Piskula MK, Osawa S, Obata H, Tobe K, Saito M, Kataoka S, Kubota Y \& Kikuchi M (2000) Soy isoflavone aglycones are absorbed faster and in higher amounts than their glucosides in humans. Journal of Nutrition 130, 1695-1699.

Jakes RW, Duffy SW, Ng FC, Gao F, Ng EH, Seow A, Lee HP \& Yu MC (2002) Mammographic parenchymal patterns and selfreported soy intake in Singapore Chinese women. Cancer Epidemiology, Biomarkers and Prevention 11, 608-613.

Jayagopal V, Albertazzi P, Kilpatrick ES, Howarth EM, Jennings PE, Hepburn DA \& Atkin SL (2002) Beneficial effects of soy phytoestrogen intake in postmenopausal women with type 2 diabetes. Diabetes Care 25, 1709-1714.

Jenkins DJ, Kendall CW, Connelly PW, Jackson CJ, Parker T, Faulkner D \& Vidgen E (2002) Effects of high- and lowisoflavone (phytoestrogen) soy foods on inflammatory biomarkers and proinflammatory cytokines in middle-aged men and women. Metabolism: Clinical and Experimental 51, 919-924.

Joannou GE, Kelly GE, Reeder AY, Waring M \& Nelson C (1995) A urinary profile study of dietary phytoestrogens - the identification and mode of metabolism of new isoflavonoids. Journal of Steroid Biochemistry and Molecular Biology 54, 167-184.

Kang HJ, Ansbacher R \& Hammoud MM (2002) Use of alternative and complementary medicine in menopause. International Journal of Gynaecology and Obstetrics 79, 195-207.

Kao YC, Zhou C, Sherman M, Laughton CA \& Chen S (1998) Molecular basis of the inhibition of human aromatase (estrogen synthetase) by flavone and isoflavone phytoestrogens: a sitedirected mutagenesis study. Environmental Health Perspectives 106, 85-92.

Kelly GE, Nelson C, Waring MA, Joannou GE \& Reeder AY (1993) Metabolites of dietary (soya) isoflavones in human urine. Clinica Chimica Acta 223, 9-22.

Kim H, Peterson TG \& Barnes S (1998) Mechanisms of action of the soy isoflavone genistein: emerging role for its effects via transforming growth factor beta signaling pathways. American Journal of Clinical Nutrition 68, 1418S-1425S.

Kirkman LM, Lampe JW, Campbell DR, Martini MC \& Slavin JL (1995) Urinary lignan and isoflavonoid excretion in men and women consuming vegetable and soy diets. Nutrition and Cancer 24, 1-12.

Kreijkamp-Kaspers S, Kok L, Grobbee DE, de Haan EHF, Aleman A, Lampe JW \& van der Schouw YT (2004) Effect of soy protein containing isoflavones on cognitive function, bone mineral density, and plasma lipids in postmenopausal women: a randomized controlled trial. JAMA 292, 65-74.

Kritz-Silverstein D, von Muhlen D, Barrett-Connor E \& Bressel MA (2003) Isoflavones and cognitive function in older women: the SOy and Postmenopausal Health In Aging (SOPHIA) study. Menopause 10, 196-202.

Kronenberg F \& Fugh-Berman A (2002) Complementary and alternative medicine for menopausal symptoms: a review of randomized, controlled trials. Annals of Internal Medicine 137, 805-813.

Kuiper G, Carlsson B, Grandien K, Enmark E, Haggblad J, Nilsson S \& Gustafsson JA (1997) Comparison of the ligand binding specificity and transcript tissue distribution of estrogen receptors alpha and beta. Endocrinology 138, 863-870.

Kuiper G, Lemmen JG, Carlsson B, Corton JC, Safe SH, van der Saag PT, van der Burg P \& Gustafsson JA (1998) Interaction of estrogenic chemicals and phytoestrogens with estrogen receptor beta. Endocrinology 139, 4252-4263.
Lafferty HM \& Brenner BM (1990) Are glomerular hypertension and hypertrophy independent risk-factors for progression of renal-disease. Seminars in Nephrology 10, 294-304.

Lamartiniere CA (2002) Timing of exposure and mammary cancer risk. Journal of Mammary Gland Biology and Neoplasia 7 , $67-76$.

Lamartiniere CA, Moore JB, Brown NM, Thompson R, Hardin MJ \& Barnes S (1995) Genistein suppresses mammary cancer in rats. Carcinogenesis 16, 2833-2840.

Lampe JW, Karr SC, Hutchins AM \& Slavin JL (1998) Urinary equol excretion with a soy challenge: influence of habitual diet. Proceedings of the Society for Experimental Biology and Medicine 217, 335-339.

Latonnelle K, Le Menn F, Kaushik SJ \& Bennetau-Pelissero C (2002) Effects of dietary phytoestrogens in vivo and in vitro in rainbow trout and Siberian sturgeon: interests and limits of the in vitro studies of interspecies differences. General and Comparative Endocrinology 126, 39-51.

Lavigne C, Marette A \& Jacques H (2000) Cod and soy proteins compared with casein improve glucose tolerance and insulin sensitivity in rats. American Journal of Physiology 278, E491-E500.

Le Lain R, Nicholls PJ, Smith HJ \& Maharlouie FH (2001) Inhibitors of human and rat testes microsomal 17betahydroxysteroid dehydrogenase (17beta-HSD) as potential agents for prostatic cancer. Journal of Enzyme Inhibition 16, 35-45.

Lephart ED, West TW, Weber KS, Rhees RW, Setchell KD, Adlercreutz H \& Lund TD (2002) Neuro behavioral effects of dietary soy phytoestrogens. Neurotoxicology and Teratology 24, $5-16$.

Lu LJ, Anderson KE, Grady JJ, Nagamani M (2002) Chronic soy consumption influences serum levels of steroid and peptide hormones without uterine effects in postmenopausal women. Journal of Nutrition 132, 615S Abstr.

Lu LJ \& Anderson KE (1998) Sex and long-term soy diets affect the metabolism and excretion of soy isoflavones in humans. American Journal of Clinical Nutrition 68, 1500S-1504S.

Lund TD, West TW, Tian LY, Bu LH, Simmons DL, Setchell KD, Adlercreutz H \& Lephart ED (2001) Visual spatial memory is enhanced in female rats (but inhibited in males) by dietary soy phytoestrogens. BMC Neuroscience 2, 20.

Lundh T (1995) Metabolism of estrogenic isoflavones in domesticanimals. Proceedings of the Society for Experimental Biology and Medicine 208, 33-39.

Lydeking-Olsen E, Beck-Jensen JE, Setchell KD \& Holm-Jensen T (2004) Soymilk or progesterone for prevention of bone loss - a 2 year randomized, placebo-controlled trial. European Journal of Nutrition 43, 246-257.

McMichael-Phillips DF, Harding C, Morton M, Roberts SA, Howell A, Potten CS \& Bundred NJ (1998) Effects of soyprotein supplementation on epithelial proliferation in the histologically normal human breast. American Journal of Clinical Nutrition 68, 1431S-1436S.

McPherson K (2004) Where are we now with hormone replacement therapy? It works for symptoms but is not good for future health. BMJ 328, 357-358.

Maddox DA, Alavi FK, Silbernick EM \& Zawada ET (2002) Protective effects of a soy diet in preventing obesity-linked renal disease. Kidney International 61, 96-104.

Makela S, Poutanen M, Kostlan ML, Lehtimaki N, Strauss L, Santti R \& Vihko R (1998) Inhibition of 17 beta-hydroxysteroid oxidoreductase by flavonoids in breast and prostate cancer cells. Proceedings of the Society for Experimental Biology and Medicine 217, 310-316.

Markiewicz L, Garey J, Adlercreutz H \& Gurpide E (1993) Invitro bioassays of nonsteroidal phytoestrogens. Journal of Steroid Biochemistry and Molecular Biology 45, 399-405. 
Maskarinec GF, Williams AE \& Carlin L (2003) Mammographic densities in a one-year isoflavone intervention. European Journal of Cancer Prevention 12, 165-169.

Messina M \& Hughes C (2003) Efficacy of soyfoods and soybean isoflavone supplements for alleviating menopausal symptoms is positively related to initial hot flush frequency. Journal of Medicinal Food 6, 1-11.

Messina MJ \& Loprinzi CL (2001) Soy for breast cancer survivors: a critical review of the literature. Journal of Nutrition 131, 3095S-3108S.

Miodini P, Fioravanti L, Di Fronzo G \& Cappelletti V (1999) The two phyto-oestrogens genistein and quercetin exert different effects on oestrogen receptor function. British Journal of Cancer 80, 1150-1155.

Mitchell JH, Gardner PT, McPhail DB, Morrice PC, Collins AR \& Duthie GG (1998) Antioxidant efficacy of phytoestrogens in chemical and biological model systems. Archives of Biochemistry and Biophysics 360, 142-148.

Montano MM \& Katzenellenbogen BS (1997) The quinone reductase gene: a unique estrogen receptor-regulated gene that is activated by antiestrogens. Proceedings of the National Academy of Sciences of the USA 94, 2581-2586.

Morabito N, Crisafulli A, Vergara C, Gaudio A, Lasco A, Frisina N, D'Anna R, Corrado F, Pizzoleo MA, Cincotta M, Altavilla D, Ientile R \& Squadrito F (2002) Effects of genistein and hormone-replacement therapy on bone loss in early postmenopausal women: a randomized double-blind placebo-controlled study. Journal of Bone and Mineral Research 17, 1904-1912.

Munro IC, Harwood M, Hlywka JJ, Stephen AM, Doull J, Flamm WG \& Adlercreutz H (2003) Soy isoflavones: a safety review. Nutrition Reviews 61, 1-33.

Murkies AL, Lombard C, Strauss BJ, Wilcox G, Burger HG \& Morton MS (1995) Dietary flour supplementation decreases post-menopausal hot flushes: effect of soy and wheat. Maturitas 21, 189-195.

Murphy PA, Song T, Buseman G, Barua K, Beecher GR, Trainer D \& Holden J (1999) Isoflavones in retail and institutional soy foods. Journal of Agricultural and Food Chemistry 47, 2697-2704.

Murray MJ, Meyer WR, Lessey BA, Oi RH, DeWire RE \& Fritz MA (2003) Soy protein isolate with isoflavones does not prevent estradiol-induced endometrial hyperplasia in postmenopausal women: a pilot trial. Menopause 10, 456-464.

Nagata C, Shimizu H, Takami R, Hayashi M, Takeda N \& Yasuda $\mathrm{K}$ (1999) Hot flushes and other menopausal symptoms in relation to soy product intake in Japanese women. Climacteric $\mathbf{2}$, $6-12$.

Nagata C, Takatsuka N, Kawakami N \& Shimizu H (2001) Soy product intake and hot flashes in Japanese women: results from a community-based prospective study. American Journal of Epidemiology 153, 790-793.

Nagata C, Takatsuka N, Kurisu Y \& Shimizu H (1998) Decreased serum total cholesterol concentration is associated with high intake of soy products in Japanese men and women. Journal of Nutrition 128, 209-213.

Nagel SC, vom Saal FS \& Welshons WV (1998) The effective free fraction of estradiol and xenoestrogens in human serum measured by whole cell uptake assays: physiology of delivery modifies estrogenic activity. Proceedings of the Society for Experimental Biology and Medicine 217, 300-309.

Nestel PJ, Pomeroy S, Kay S, Komesaroff P, Behrsing J, Cameron JD \& West L (1999) Isoflavones from red clover improve systemic arterial compliance but not plasma lipids in menopausal women. Journal of Clinical Endocrinology and Metabolism 84, 895-898.
Nilsson S, Kuiper G \& Gustafsson JA (1998) ER beta: a novel estrogen receptor offers the potential for new drug development. Trends in Endocrinology and Metabolism 9, 387-395.

Pansini F, Bonaccorsi G \& Albertazzi P (1997) Soy phytoestrogens and bone. Proceedings of the North American Menopause Society 44.

Peeters PHM, Keinan-Boker L, van der Schouw YT \& Grobbee DE (2003) Phytoestrogens and breast cancer risk - review of the epidemiological evidence. Breast Cancer Research and Treatment 77, 171-183.

Penotti M, Fabio E, Modena AB, Rinaldi M, Omedei U \& Vigano P (2003) Effect of soy-derived isoflavones on hot flushes, endometrial thickness, and the pulsatility index of the uterine and cerebral arteries. Fertility and Sterility 79, 1112-1117.

Petrakis NL, Barnes S, King EB, Lowenstein J, Wiencke J, Lee MM, Miike R, Kirk M \& Coward L (1996) Stimulatory influence of soy protein isolate on breast secretion in pre- and postmenopausal women. Cancer Epidemiology Biomarkers and Prevention 5, 785-794.

Pike ACW, Brzozowski AM, Hubbard RE, Bonn T, Thorsell AG, Engstrom O, Ljunggren J, Gustafsson JK \& Carlquist M (1999) Structure of the ligand-binding domain of oestrogen receptor beta in the presence of a partial agonist and a full antagonist. EMBO Journal 18, 4608-4618.

Pinnell SR (2003) Cutaneous photodamage, oxidative stress, and topical antioxidant protection. Journal of the American Academy of Dermatology 48, 1-22.

Potter SM, Baum JA, Teng H, Stillman RJ, Shay NF \& Erdman JW $\mathrm{Jr}$ (1998) Soy protein and isoflavones: their effects on blood lipids and bone density in postmenopausal women. American Journal of Clinical Nutrition 68, 1375S-1379S.

Powles T (2004) Isoflavones and women's health. Breast Cancer Research 6, 140-142.

Ranich T, Bhathena SJ \& Velasquez MT (2001) Protective effects of dietary phytoestrogens in chronic renal disease. Journal of Renal Nutrition 11, 183-193.

Register TC \& Adams MR (1998) Coronary artery and cultured aortic smooth muscle cells express mRNA for both the classical estrogen receptor and the newly described estrogen receptor beta. Journal of Steroid Biochemistry and Molecular Biology 64, 187-191.

Rimbach G, Weinberg PD, de Pascual-Teresa S, Alonso MG, Ewins BA, Turner R, Minihane AM, Botting N, Fairley B, Matsugo S, Uchida Y \& Cassidy A (2004) Sulfation of genistein alters its antioxidant properties and its effect on platelet aggregation and monocyte and endothelial function. Biochimica et Biophysica Acta 1670, 229-237.

Rivas M, Garay RP, Escanero JF, Cia P \& Alda JO (2002) Soy milk lowers blood pressure in men and women with mild to moderate essential hypertension. Journal of Nutrition 132, 1900-1902.

Rossouw JE, Anderson GL, Prentice RL, LaCroix AZ, Kooperberg C, Stefanick ML, Jackson RD, Beresford SAA, Howard BV, Johnson KC, Kotchen M \& Ockene J (2002) Risks and benefits of estrogen plus progestin in healthy postmenopausal women principal results from the Women's Health Initiative randomized controlled trial. JAMA 288, 321-333.

Rowland I, Faughnan M, Hoey L, Wahala K, Williamson G \& Cassidy A (2003) Bioavailability of phyto-oestrogens. British Journal of Nutrition 89, S45-S58.

Rowland I, Wiseman H, Sanders T, Adlercreutz H \& Bowey E (1999) Metabolism of oestrogens and phytoestrogens: role of the gut microflora. Biochemical Society Transactions 27, 304-308.

Rowland IR, Wiseman H, Sanders TA, Adlercreutz H \& Bowey EA (2000) Interindividual variation in metabolism of soy isoflavones and lignans: influence of habitual diet on equol production by the gut microflora. Nutrition and Cancer 36, $27-32$. 
Rubanyi GM, Kauser K \& Johns A (2002) Role of estrogen receptors in the vascular system. Vascular Pharmacology 38, $81-88$.

Sader MA \& Celermajer DS (2002) Endothelial function, vascular reactivity and gender differences in the cardiovascular system. Cardiovascular Research 53, 597-604.

Samman S, Lyons Wall PM, Chan GS, Smith SJ \& Petocz P (1999) The effect of supplementation with isoflavones on plasma lipids and oxidisability of low density lipoprotein in premenopausal women. Atherosclerosis 147, 277-283.

Sathyamoorthy N, Gilsdorf JS \& Wang TT (1998) Differential effect of genistein on transforming growth factor beta 1 expression in normal and malignant mammary epithelial cells. Anticancer Research 18, 2449-2453.

Scambia G, Mango D, Signorile PG, Angeli RA, Palena C, Gallo D, Bombardelli E, Morazzoni P, Riva A \& Mancuso S (2000) Clinical effects of a standardized soy extract in postmenopausal women: a pilot study. Menopause - the Journal of the North American Menopause Society 7, 105-111.

Schaffer P (1997) Epidemiology of cervical and endometrial cancer. Bulletin De L'Academie Nationale De Medecine 181, $1347-1364$

Scheiber MD, Liu JH, Subbiah MTR, Rebar RW \& Setchell KDR (2001) Dietary inclusion of whole soy foods results in significant reductions in clinical risk factors for osteoporosis and cardiovascular disease in normal postmenopausal women. Menopause - the Journal of the North American Menopause Society 8, 384-392.

Secreto G, Chiechi LM, Amadori A, Miceli R, Venturelli E, Valerio $\mathrm{T} \&$ Marubini E (2004) Soy isoflavones and melatonin for the relief of climacteric symptoms: a multicenter, double-blind, randomized study. Maturitas 47, 11-20.

Seow A, Shi CY, Franke AA, Hankin JH, Lee HP \& Yu MC (1998) Isoflavonoid levels in spot urine are associated with frequency of dietary soy intake in a population-based sample of middle-aged and older Chinese in Singapore. Cancer Epidemiology Biomarkers and Prevention 7, 135-140.

Setchell KD, Brown NM, Desai P, Zimmer-Nechemias L, Wolfe BE, Brashear WT, Kirschner AS, Cassidy A \& Heubi JE (2001) Bioavailability of pure isoflavones in healthy humans and analysis of commercial soy isoflavone supplements. Journal of Nutrition 131, 1362S-1375S.

Setchell KD, Brown NM, Desai PB, Zimmer-Nechimias L, Wolfe B, Jakate AS, Creutzinger V \& Heubi JE (2003a) Bioavailability, disposition, and dose-response effects of soy isoflavones when consumed by healthy women at physiologically typical dietary intakes. Journal of Nutrition 133, 1027-1035.

Setchell KD, Brown NM \& Lydeking-Olsen E (2002a) The clinical importance of the metabolite equol - a clue to the effectiveness of soy and its isoflavones. Journal of Nutrition 132, 3577-3584.

Setchell KD \& Cole SJ (2003) Variations in isoflavone levels in soy foods and soy protein isolates and issues related to isoflavone databases and food labeling. Journal of Agricultural and Food Chemistry 51, 4146-4155.

Setchell KD, Faughnan MS, Avades T, Zimmer-Nechemias L, Brown NM, Wolfe BE, Brashear WT, Desai P, Oldfield MF, Botting NP \& Cassidy A (2003b) Comparing the pharmacokinetics of daidzein and genistein with the use of 13C-labeled tracers in premenopausal women. American Journal of Clinical Nutrition 77, 411-419.

Setchell KD \& Lydeking-Olsen E (2003) Dietary phytoestrogens and their effect on bone: evidence from in vitro and in vivo, human observational, and dietary intervention studies. American Journal of Clinical Nutrition 78, 593S-609S.

Setchell KD, Zimmer-Nechemias L, Cai J \& Heubi JE (1997) Exposure of infants to phyto-oestrogens from soy-based infant formula. Lancet 350, 23-27.
Setchell KDR (1998) Phytoestrogens: the biochemistry, physiology, and implications for human health of soy isoflavones. American Journal of Clinical Nutrition 68, 1333S-1346S.

Setchell KDR, Borriello SP, Hulme P, Kirk DN \& Axelson M (1984) Nonsteroidal estrogens of dietary origin - possible roles in hormone-dependent disease. American Journal of Clinical Nutrition 40, 569-578.

Setchell KDR, Brown NM \& Lydeking-Olsen E (2002b) The clinical importance of the metabolite equol - a clue to the effectiveness of soy and its isoflavones. Journal of Nutrition 132, 3577-3584.

Setchell KDR \& Cassidy A (1999) Dietary isoflavones: biological effects and relevance to human health. Journal of Nutrition 129, $758 \mathrm{~S}-767 \mathrm{~S}$.

Shu XO, Brinton LA, Zheng W, Gao YT, Fan J \& Fraumeni JF (1991) A population-based case-control study of endometrial cancer in Shanghai, China. International Journal of Cancer 49, $38-43$.

Shutt DA \& Cox RI (1972) Steroid and phyto-oestrogen binding to sheep uterine receptors in vitro. Journal of Endocrinology 52, 299-310.

Shyong EQ, Lu Y, Lazinsky A, Saladi RN, Phelps RG, Austin LM, Lebwohl M \& Wei H (2002) Effects of the isoflavone 4',5,7-trihydroxyisoflavone, (genistein) on psoralen plus ultraviolet A radiation, (PUVA)-induced photodamage. Carcinogenesis 23, 317-321.

Simons LA, von Konigsmark M, Simons J \& Celermajer DS (2000) Phyto-oestrogens do not influence lipoprotein levels or endothelial function in healthy, postmenopausal women. American Journal of Cardiology 85, 1297-1301.

Solanky KS, Bailey NJC, Beckwith-Hall BM, Davis A, Bingham S, Holmes E, Nicholson JK \& Cassidy A (2003) Application of biofluid $\mathrm{H}-1$ nuclear magnetic resonance-based metabonomic techniques for the analysis of the biochemical effects of dietary isoflavones on human plasma profile. Analytical Biochemistry 323, 197-204

Somekawa Y, Chiguchi M, Ishibashi T \& Aso T (2001) Soya intake related to menopausal symptoms, serum lipids, and bone mineral density in postmenopausal Japanese women. Obstetrics and Gynecology 97, 109-115.

Steinberg FM, Guthrie NL, Villablanca AC, Kumar K \& Murray MJ (2003) Soy protein with isoflavones has favorable effects on endothelial function that are independent of lipid and antioxidant effects in healthy postmenopausal women. American Journal of Clinical Nutrition 78, 123-130.

Teede HJ, Dalais FS, Kotsopoulos D, Liang YL, Davis S \& McGrath BP (2001) Dietary soy has both beneficial and potentially adverse cardiovascular effects: a placebo-controlled study in men and postmenopausal women. Journal of Clinical Endocrinology and Metabolism 86, 3053-3060.

Teede HJ, McGrath BP, DeSilva L, Cehun M, Fassoulakis A \& Nestel PJ (2003) Isoflavones reduce arterial stiffness a placebo-controlled study in men and postmenopausal women. Arteriosclerosis Thrombosis and Vascular Biology 23, 1066-1071.

Tice JA, Ettinger B, Ensrud K, Wallace R, Blackwell T \& Cummings SR (2003) Phytoestrogen supplements for the treatment of hot flashes: the Isoflavone Clover Extract, (ICE) Study: a randomized controlled trial. JAMA 290, 207-214.

Tobias JH, Cook DG, Chambers TJ \& Dalzell N (1994) A comparison of bone-mineral density between Caucasian, Asian and Afro-Caribbean Women. Clinical Science 87, 587-591.

Turner R, Baron T, Wolffram S, Minihane AM, Cassidy A, Rimbach G \& Weinberg PD (2004) Effect of circulating forms of soy isoflavones on the oxidation of low density lipoprotein. Free Radical Research 38, 209-216. 
Uesugi T, Fukui Y \& Yamori Y (2002) Beneficial effects of soybean isoflavone supplementation on bone metabolism and serum lipids in postmenopausal japanese women: a four-week study. Journal of the American College of Nutrition 21, 97-102.

Upmalis DH, Lobo R, Bradley L, Warren M, Cone FL \& Lamia CA (2000) Vasomotor symptom relief by soy isoflavone extract tablets in postmenopausal women: a multicenter, double-blind, randomized, placebo-controlled study. Menopause 7, 236-242.

van Popele NM, Grobbee DE, Bots ML, Asman R, Topouchian J, Reneman RS, Hoeks APG, van der Kuip DAM, Hofman A \& Witteman JCM (2001) Association between arterial stiffness and atherosclerosis - The Rotterdam study. Stroke 32, 454-460.

Velasquez MT \& Bhathena SJ (2001) Dietary phytoestrogens: a possible role in renal disease protection. American Journal of Kidney Diseases 37, 1056-1068.

Vigna GB, Pansini F, Bonaccorsi G, Albertazzi P, Donega P, Zanotti L, De Aloysio D, Mollica G \& Fellin R (2000) Plasma lipoproteins in soy-treated postmenopausal women: a doubleblind, placebo-controlled trial. Nutrition Metabolism and Cardiovascular Diseases 10, 315-322.

Wade MG, Lee A, McMahon A, Cooke G \& Curran I (2003) The influence of dietary isoflavone on the uterotrophic response in juvenile rats. Food and Chemical Toxicology 41, 1517-1525.

Wagner JD, Cefalu WT, Anthony MS, Litwak KN, Zhang L \& Clarkson TB (1997) Dietary soy protein and estrogen replacement therapy improve cardiovascular risk factors and decrease aortic cholesteryl ester content in ovariectomized cynomolgus monkeys. Metabolism - Clinical and Experimental 46, 698-705.

Wahala K \& Alho S (2002) Soy isoflavones and binding sites of estrogen receptor alpha and beta and 17 beta-hydroxysteroid dehydrogenase type 1 enzyme. Journal of Nutrition 132, 591S-592S.

Wakai K, Egami I, Kato K, Kawamura T, Tamakoshi A, Lin Y, Nakayama T, Wada M \& Ohno Y (1999) Dietary intake and sources of isoflavones among Japanese. Nutrition and Cancer 33, 139-145.

Wangen KE, Duncan AM, Merz-Demlow BE, Xu X, Marcus R, Phipps WR \& Kurzer MS (2000) Effects of soy isoflavones on markers of bone turnover in premenopausal and postmenopausal women. Journal of Clinical Endocrinology and Metabolism 85, 3043-3048

Washburn S, Burke GL, Morgan T \& Anthony M (1999) Effect of soy protein supplementation on serum lipoproteins, blood pressure, and menopausal symptoms in perimenopausal women. Menopause - the Journal of the North American Menopause Society 6, 7-13.

Watanabe T, Akishita M, Nakaoka T, Kozaki K, Miyahara Y, He H, Ohike Y, Ogita T, Inoue S, Muramatsu M, Yamashita N \& Ouchi Y (2003) Estrogen receptor beta mediates the inhibitory effect of estradiol on vascular smooth muscle cell proliferation. Cardiovascular Research 59, 734-744.

Weggemans RM \& Trautwein EA (2003) Relation between soy-associated isoflavones and LDL and HDL cholesterol concentrations in humans: a meta-analysis. European Journal of Clinical Nutrition 57, 940-946.

Wei H, Saladi R, Lu Y, Wang Y, Palep SR, Moore J, Phelps R, Shyong E \& Lebwohl MG (2003) Isoflavone genistein: photoprotection and clinical implications in dermatology. Journal of Nutrition 133, 3811S-3819S.

Wei H, Wei L, Frenkel K, Bowen R \& Barnes S (1993) Inhibition of tumor promoter-induced hydrogen peroxide formation in vitro and in vivo by genistein. Nutrition and Cancer 20, 1-12.

Wei H, Zhang X, Wang Y \& Lebwohl M (2002) Inhibition of ultraviolet light-induced oxidative events in the skin and internal organs of hairless mice by isoflavone genistein. Cancer Letters 185, 21-29.

White L, Petrovitch H, Ross W, Masaki KH, Abbott RD, Teng EL, Rodriguez BL, Blanchette PL, Havlik RJ, Wergowske G, Chiu D, Foley DJ, Murdaugh C \& Curb JD (1996) Prevalence of dementia in older Japanese-American men in Hawaii - The Honolulu-Asia Aging Study. JAMA 276, 955-960.

Williams JK \& Clarkson TB (1998) Dietary soy isoflavones inhibit in-vivo constrictor responses of coronary arteries to collageninduced platelet activation. Coronary Artery Disease 9, $759-764$.

Wong WW (2000) Effects of soy isoflavone on blood lipids, blood pressure, and biochemical markers of bone metabolism in postmenopausal women. Journal of Nutrition 130, 686S.

Xu WH, Zheng W, Xiang YB, Ruan ZM, Cheng JR, Dai Q, Gao YT \& Shu XO (2004) Soya food intake and risk of endometrial cancer among Chinese women in Shanghai: population based case-control study. BMJ 328, 1285-1288.

Xu X, Duncan AM, Merz BE \& Kurzer MS (1998) Effects of soya isoflavones on estrogen and phytoestrogen metabolism in premenopausal women. Cancer Epidemiology, Biomarkers and Prevention 7, 1101-1108.

Xu X, Wang HJ, Murphy PA, Cook L \& Hendrich S (1994) Daidzein is a more bioavailable soymilk isoflavone than is genistein in adult women. Journal of Nutrition 124, 825-832.

Yamamoto S, Sobue T, Kobayashi M, Sasaki S \& Tsugane S (2003) Soy, isoflavones, and breast cancer risk in Japan. Journal of the National Cancer Institute 95, 906-913.

Yildirir A, Tokgozoglu SL, Oduncu T, Oto A, Haznedaroglu I, Akinci D, Koksal G, Sade E, Kirazli S \& Kes S (2001) Soy protein diet significantly improves endothelial function and lipid parameters. Clinical Cardiology 24, 711-716.

Yoles I, Yogev Y, Frenkel Y, Nahum R, Hirsch M \& Kaplan B (2003) Tofupill/Femarelle (DT56a): a new phyto-selective estrogen receptor modulator-like substance for the treatment of postmenopausal bone loss. Menopause 10, 522-525.

Zava DT, Blen M \& Duwe G (1997) Estrogenic activity of natural and synthetic estrogens in human breast cancer cells in culture. Environmental Health Perspectives 105, 637-645.

Zubik L \& Meydani M (2003) Bioavailability of soybean isoflavones from aglycone and glucoside forms in American women. American Journal of Clinical Nutrition 77, 1459-1465. 